\title{
Any Place for Immunohistochemistry within the Predictive Biomarkers of Treatment in Lung Cancer Patients?
}

\author{
Véronique Hofman ${ }^{1,2}$, Sandra Lassalle ${ }^{1,2}$, Coraline Bence ${ }^{1,2}$, Elodie Long-Mira ${ }^{1,2}$, \\ Sacha Nahon-Estève ${ }^{1}$, Simon Heeke ${ }^{1}$, Virginie Lespinet-Fabre ${ }^{1}$, Catherine Butori ${ }^{1,2}$, \\ Marius Ilié 1,2 (D) and Paul Hofman 1,2,* \\ 1 Laboratory of Clinical and Experimental Pathology, Côte d'Azur University, FHU OncoAge, \\ Pasteur Hospital, 30 Avenue de la voie Romaine, 06001 Nice CEDEX 01, France; \\ hofman.v@chu-nice.fr (V.H.); lassalle.s@chu-nice.fr (S.L.); bence.c@chu-nice.fr (C.B.); \\ long-mira.e@chu-nice.fr (E.L.-M.); nahon-esteve.s@chu-nice.fr (S.N.-E.); heeke.s@chu-nice.fr (S.H.); \\ lespinet-fabre.v@chu-nice.fr (V.L.-F.); Butori.c@chu-nice.fr (C.B.); ilie.m@chu-nice.fr (M.I.) \\ 2 Hospital-Integrated Biobank (BB-0033-00025), Pasteur Hospital, 30 Avenue de la voie Romaine, \\ 06001 Nice CEDEX 01, France \\ * Correspondence: hofman.p@chu-nice.fr; Tel.: +33-4-9203-8855; Fax: +33-4-9203-8750
}

Received: 27 January 2018; Accepted: 9 March 2018; Published: 13 March 2018

\begin{abstract}
The identification of certain genomic alterations (EGFR, ALK, ROS1, BRAF) or immunological markers (PD-L1) in tissues or cells has led to targeted treatment for patients presenting with late stage or metastatic lung cancer. These biomarkers can be detected by immunohistochemistry (IHC) and/or by molecular biology (MB) techniques. These approaches are often complementary but depending on, the quantity and quality of the biological material, the urgency to get the results, the access to technological platforms, the financial resources and the expertise of the team, the choice of the approach can be questioned. The possibility of detecting simultaneously several molecular targets, and of analyzing the degree of tumor mutation burden and of the micro-satellite instability, as well as the recent requirement to quantify the expression of PD-L1 in tumor cells, has led to case by case development of algorithms and international recommendations, which depend on the quality and quantity of biological samples. This review will highlight the different predictive biomarkers detected by IHC for treatment of lung cancer as well as the present advantages and limitations of this approach. A number of perspectives will be considered.
\end{abstract}

Keywords: predictive biomarkers; lung cancer; immunohistochemistry; immunocytochemistry; immune-oncology

\section{Introduction}

Technological progress, the discoveries made by fundamental research laboratories and the development of translational research performed in particular thanks to biobanks, as well as the availability of precisely annotated clinical samples have resulted in the emergence of biomarkers associated to novel therapeutics for patients with lung cancer [1-4]. While it is now mandatory to look for some of these biomarkers, since they are associated to the efficacy of validated treatments and are accessible, other biomarkers are evaluated in therapeutic trials, as well as in clinical and exploratory research protocols [5-8]. When considering biomarkers of interest, the sensitivity and specificity of the tests aimed at their identification must be evaluated and compared. Participation in external evaluation of the quality is a prerequisite before implementation by a laboratory of predictive biological tests for therapeutic response [9-11]. When considering the therapeutic issues, the benefit-risk balance 
for patients and the management of economic models related to public health, it is essential to use a reliable biomarker [12].

The increase in the number of biomarkers for evaluation in a patient with late stage or metastatic lung cancer raises several problems: (i) Is it possible to look sequentially for several biomarkers? (ii) Should the panels be used systematically at a single time? (iii) Can immunohistochemistry (IHC) or molecular biology (MB) methods be combined using small-sized tissue samples or cytological samples?

This review will summarize the main therapeutic targets detected with IHC for care of patients with non-small cell lung cancer (NSCLC) or small cell lung cancer (SCLC). It will specify the circumstance under which this approach is appropriated for personalized medicine and compare it to the possibilities proposed by techniques of MB.

\section{Tissue and Cell Samples and the Management of Daily Practice}

The techniques for getting tissue and cytological specimens that provide diagnosis of lung cancers have evolved, have become less invasive and now also evaluate the metastatic stage, in particular for mediastinal lymph nodes [13-16]. These techniques give more and more distal access to small lesions of the bronchial tree [13-16]. However, it became progressively apparent that one of the constraints of these new methods was that they provided small and fragmented amounts of tissue instead of larger and complete tissue samples. Thus, when conducting morphological and/or molecular approaches the available morphological material must be considered [17,18] (Figure 1). The sensitivity of the detection method of the different molecular targets, as well as their specificity, mean that, depending on the case, one of these methods cannot be performed or else reservation concerning the solidity or reliability of the results may be issued. Beyond the nature and quantity of the available biological material, pre-analytical steps must control the type and the fixation time due to their impact on the quality of the nucleic acids and proteins $[19,20]$. Aside from the length of the cold ischemia (delay between sampling and fixation), which is generally very short for thoracic biopsies, the pre-analytical steps must master the type and the time duration of fixation while taking into consideration their impact on the quality of the nucleic acids and proteins $[19,21]$. Thus, the use of solutions other than formol is not recommended for IHC since the degradation of certain epitopes makes the interpretation of the detection of different signals inexact $[19,21]$.

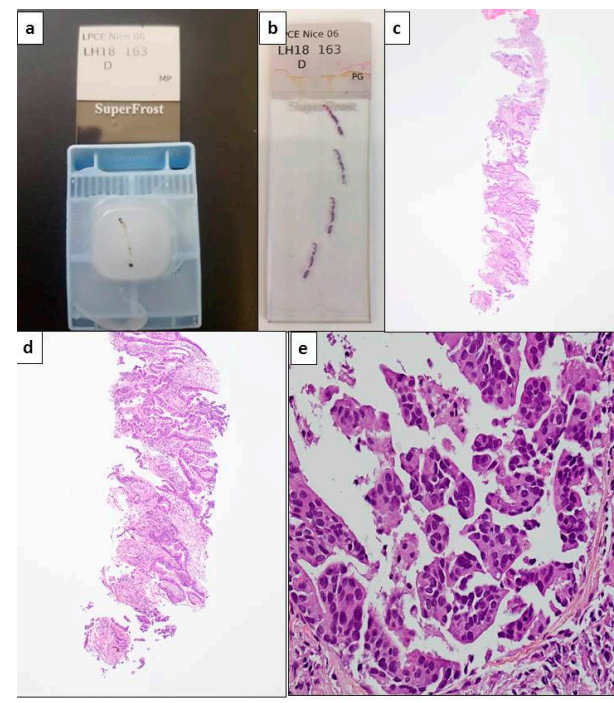

(A)

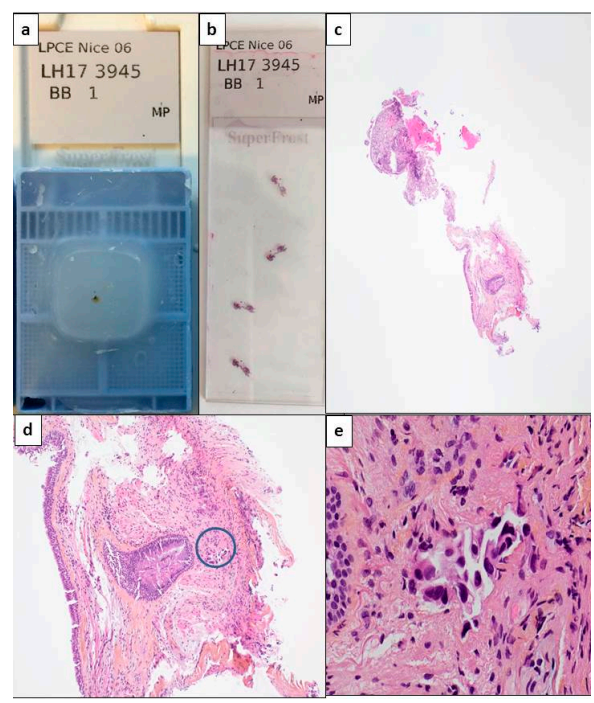

(B)

Figure 1. Cont. 


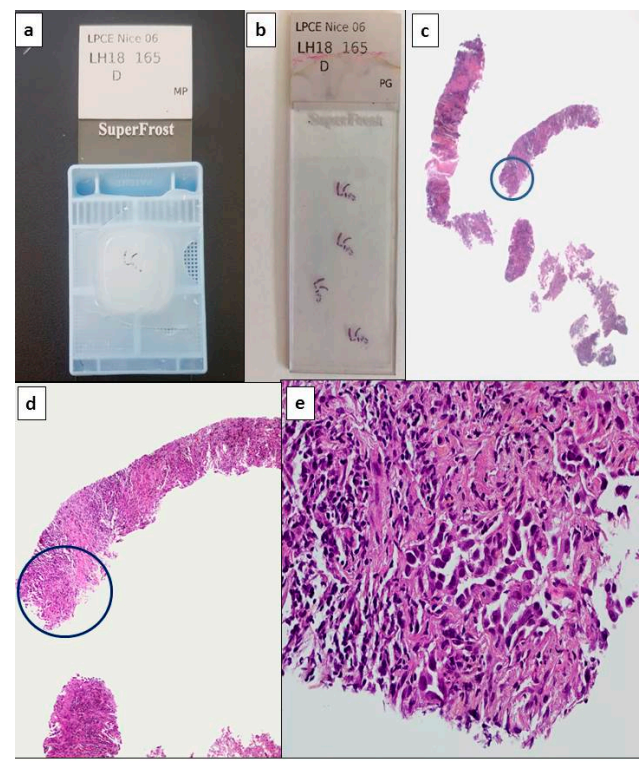

(C)

Figure 1. Potential scenarios for detection of theranostic biomarkers for lung adenocarcinomas using thoracic biopsies. Depending on the quantity of tumor cells detected on hematoxylin and eosin stained sections, immunohistochemistry (IHC) and/or molecular biology approaches can be used (with or without panels). (A) Large biopsy with a high percentage of tumor cells (more than 50\%). Paraffin block with one biopsy (a) and corresponding 4 tissue sections stained with hematoxylin eosin (b). Different magnifications of the same tissue section showing high number of adenocarcinoma cells (c-e). In this latter case, the number of tumor cells should allow PD-L1 IHC to be performed first and then followed by NGS. Alternatively a workflow including successive PD-L1, ALK, ROS1, and BRAF IHC, and then NGS can be also adopted. (B) Small biopsies with a few tumor cells. Paraffin block with small biopsies (a) and corresponding 4 tissue sections stained with hematoxylin eosin (b). Different magnifications of the same tissue section showing in only one area (circle) a low number of tumor cells (no more than 15 tumor cells) (c-e). IHC targeting PD-L1, then IHC for EGFR, ALK, ROS1, and BRAF should be probably done. (C) Large biopsies with a low percentage of tumor cells (less than 5\%). Paraffin block with at least 5 large biopsies (a) and corresponding 4 tissue sections stained with hematoxylin eosin (b). Different magnifications of the same tissue section showing in only one area (circle) some tumor cells (c-e). IHC for PD-L1 then successively for ALK, ROS1 and BRAF can be done and followed by targeted molecular biology for detection of EGFR mutations on a single tissue section or alternatively IHC for EGFR, according to the sensitivity of the MB test [1Ac, $1 \mathrm{Bc}$, $1 \mathrm{Cc}$, original magnification $\times 25$; $1 \mathrm{Ad}, 1 \mathrm{Bd}, 1 \mathrm{Cd}$, original magnification $\times 100$; $1 \mathrm{Ae}, 1 \mathrm{Be}, 1 \mathrm{Ce}$, original magnification $\times 400]$.

Of particular importance, alcohol fixation of cytological samples for ICC gives variable results depending on the antibody and the epitope for identification [22]. This type of fixation is not recommended in the absence of comparative analyses and validation with samples treated with formol. The time of fixation with formol must be controlled. In particular, hypofixation of a tissue biopsy (in general less than 6-8 h) can have a substantial impact on the results of IHC. Inappropriate fixation has also important consequences on the quality of the molecular analyses [fluorescence in situ hybridization (FISH) or sequencing techniques]. The degradation of nucleic acids (DNA and RNA) after over- or under-fixation or fixation with a solution other than formol makes the MB techniques noncontributory [23]. Finally decalcification/pre-treatment conditions used before bone tissue sectioning are usually unsatisfactory for IHC as well as for MB approaches [19]. 


\section{The Therapeutic Targets Identified by Immunohistochemistry in Thoracic Oncology}

Several therapeutic targets can be detected in the daily practice using antibodies for IHC. The anti-ALK, anti-ROS1, anti-EGFR mutated, anti-BRAF V600E, anti-NTRK, and anti-PD-L1 can potentially be used by pathologist on tissue material (bronchial or transthoracic biopsies in particular) (Figures 2 and 3). The use of these antibodies with formol fixed cytological material requires validation steps and comparative approaches with results obtained with tissue biopsies performed preferably on the same patient. In general, the cytological samples examined after formol fixation and inclusion into paraffin blocks (cytoblocks) give similar results to those obtained with tissue samples [24-27]. The other cytological approaches (absence of fixation, fixation other than with formol, cytological smears, cytology after centrifugation onto slides) make standardization of ICC approaches difficult. The sensitivity of the different antibodies is generally very good in the event of appropriate management of the pre-analytical phases. Their specificity must be considered and controlled according to the clone for use. Some clones are used only for companion diagnostic tests approved by the Food and Drug Administration (FDA) in the USA and have thus been validated in comparison with the efficacy of the administrated therapeutic molecule, while other clones are evaluated in laboratories as laboratory developed tests (LDT) and require strong caution for clinical validation [28].

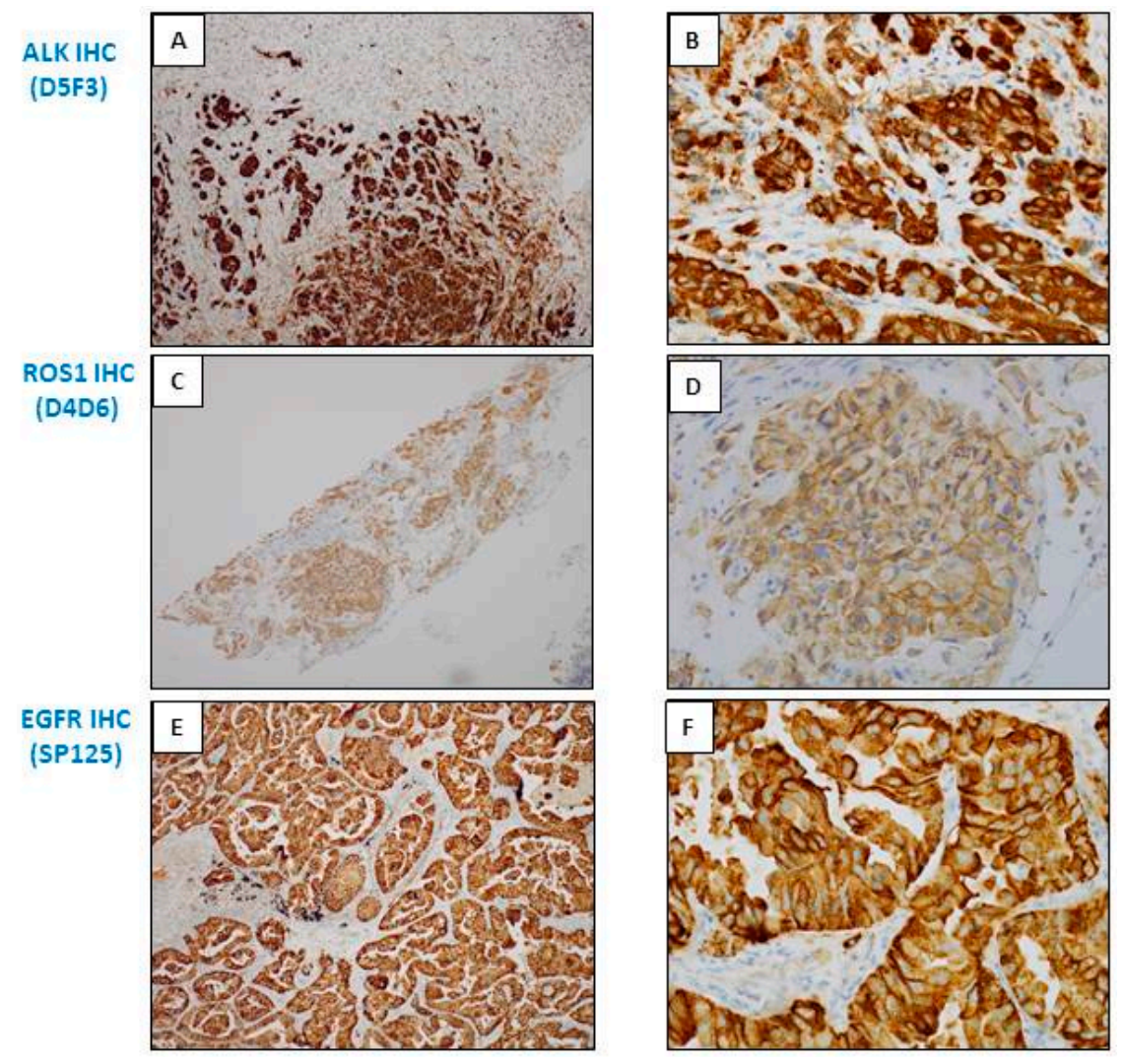

Figure 2. Cont. 

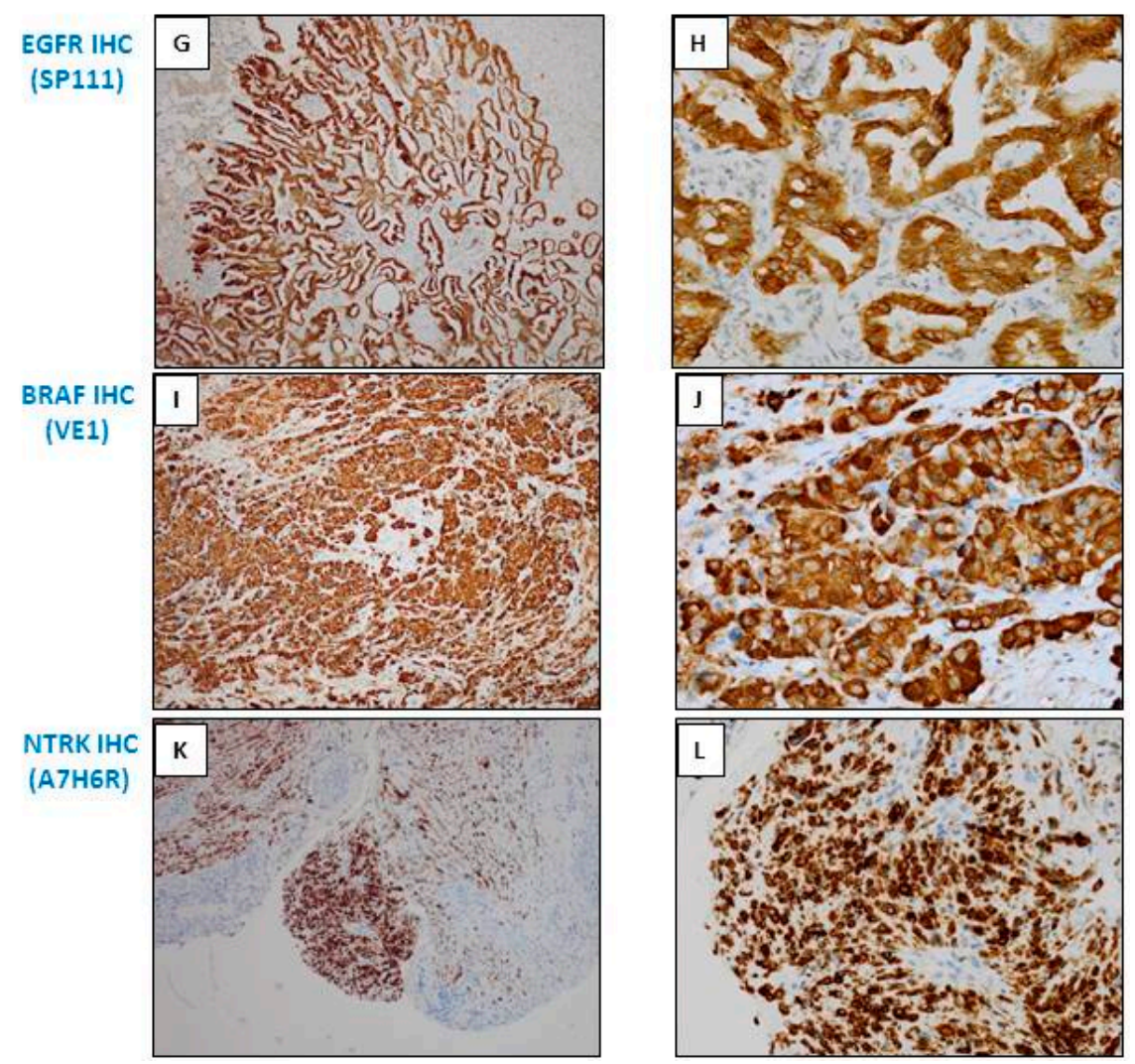

Figure 2. Examples of different types of staining of immunohistochemistry (IHC) obtained with bronchial biopsies with antibodies used as theranostic tools for lung adenocarcinoma. (A,B) ALK IHC (D5F3, Ventana); (C,D) ROS1 IHC (D4D6, Cell Signaling); (E,F) EGFR IHC (L858 EGFR mutation; SP125, Ventana); (G,H) EGFR IHC (del 19 EGFR mutation; SP111, Ventana); (I,J) BRAF V600E IHC (VE1, Ventana); (K,L) pan Trk IHC (A7H6R, Cell Signaling). (A,C,E,G,I,K) Immunoperoxidase, magnification $\times 100 ;(\mathbf{B}, \mathbf{D}, \mathbf{F}, \mathbf{H}, \mathbf{J}, \mathbf{L})$ Immunoperoxidase, magnification $\times 400$.
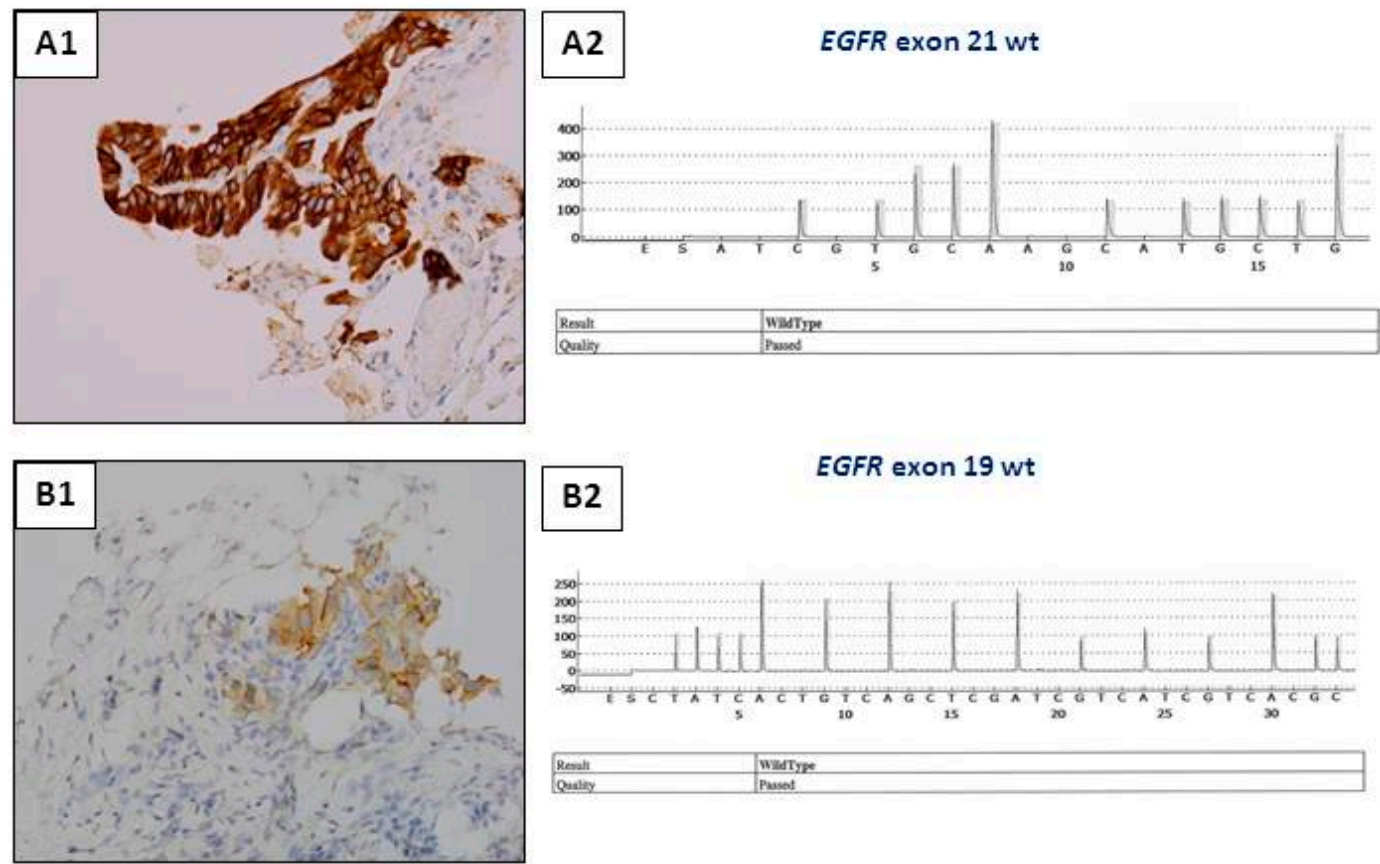

B2

EGFR exon $19 \mathrm{wt}$

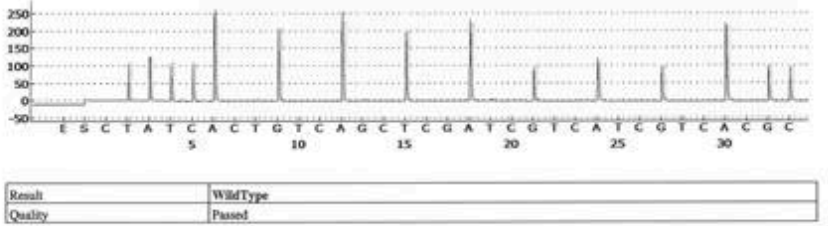

Figure 3. Cont. 

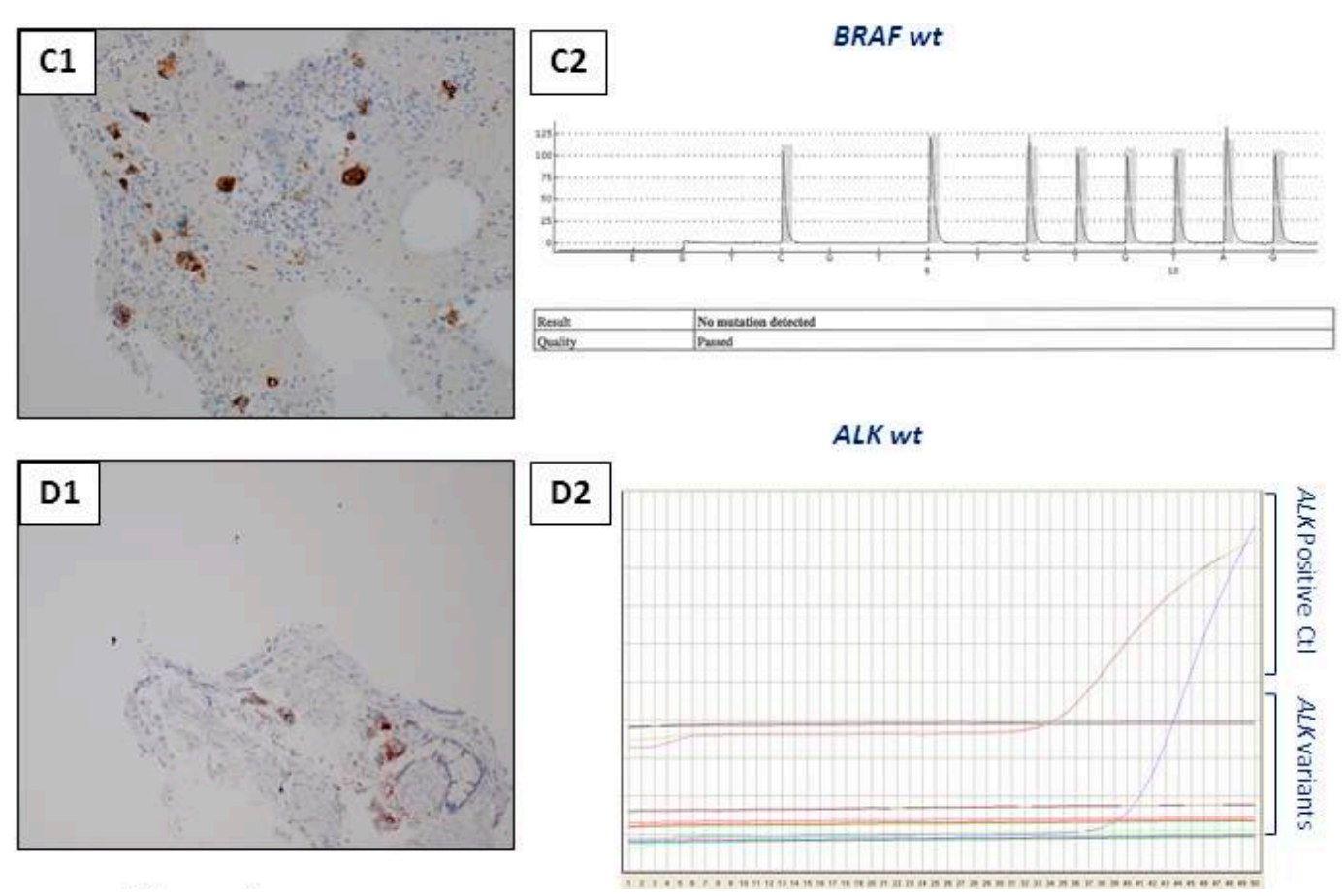

Figure 3. Examples of interest for use of IHC as a unique tool for theranostic biomarker detection in biopsies with a few tumor cells. (A) L858R EGFR mutation detection. (A1) Positive EGFR IHC using the SP125 clone. (A2) A negative molecular biology result (using a pyrosequencing/therascreen EGFR panel from Qiagen, Hilden, Germany) for detection of the L858R EGFR mutation with the same biopsy. (B) Detection of the Del 19 EGFR mutation. (B1) Positive EGFR IHC using the SP111 clone. (B2) A negative molecular biology result (using a pyrosequencing/therascreen EGFR panel from Qiagen, Hilden, Germany) for the Del 19 mutation in EGFR detected in the same biopsy. (C) Detection of the BRAF V600E mutation. (C1) Positive BRAFV600E IHC using the VE1 clone. (C2) A negative molecular biology result (using a pyrosequencing/therascreen $B R A F$ panel from Qiagen) for detection of a BRAF mutation. (D) $A L K$ status detection. (D1) ALK status assessment. (D1) A positive ALK IHC using the D5F3 clone. (D2) A negative molecular result for detection of a $A L K$ rearrangement [using RT-PCR targeting the variants 1 (E13; A20), 2 (E20; A20), 3A and 3B (E06; A20), 5 (E02; A20) and 7 (E17; A20) of ALK].

\subsection{Anti-ALK Antibodies}

These antibodies are routinely used in most pathology laboratories [29]. The D5F3 clone (Ventana, Tucson, AZ, USA) is a companion diagnostic test validated by the FDA [30,31]. It is often used and its sensitivity and specificity are excellent [32]. However, it should only be used with the Ventana platform (Roche Diagnostic, Tucson, AZ, USA) and its cost can be higher than other clones. Modification can be required when using the Benchmark Ultra (Ventana) compared to the Benchmark XT (Ventana), where some non-specific labeling can be visible (personal data). However, the D5F3 clone can be used in other IHC platforms than the Ventana platforms and as a laboratory developed test (LDT). The other clone the most often used is the 5A4 clone (Abcam, Cambridge, UK) [33]. Discordant results are sometimes obtained, depending on the study, some of which reveal lower sensitivity and less specificity than the D5F3 clone [30]. Other anti-ALK antibodies have been developed, but the tests of comparative and multi-center validation are strongly recommended before use in the routine clinic [34]. Thus, disregarding the clone for use quality controls must be performed before performing ALK IHC in the daily practice, knowing the therapeutic consequences associated to the obtained results [35-37]. Moreover, since these ALK IHC are rarely positive in NSCLC it must be mandatory to use ALK positive and negative samples as controls in parallel. While the FISH technique represented for a longtime the gold standard approach for the analysis of the $A L K$ status, and a positive result on IHC required systematic validation of the status by FISH, recent recommendations indicate than 
intense labeling with the clone D5F3 on IHC is now sufficient for treatment of the patient with ALK inhibitors [34]. This is all the more important given that FISH ALK is more sensitive that ALK IHC to pre-analytical variables (in particular to poor fixation) and can turn out to be negative due to nucleic acid modification [38]. However when a weak or a moderate labeling with the clone D5F3 is observed, $A L K$ FISH must be done in order to confirm the results. The use of anti-ALK antibodies for ICC is possible if the above precautions are observed $[39,40]$. At present, confirmation by FISH is required if a positive ALK result is obtained by ICC. One of the limitations of FISH for ALK on cytological samples is the number of tumor cells, which is sometimes less than 100 thereby making difficult the analysis as a function of the required cut off [40].

\subsection{Anti-ROS1 Antibodies}

Only a few anti-ROS1 antibodies have been validated and recommended for use in daily routine practice [41-44]. The D4D6 (Cell Signaling Technology, Leiden, The Netherlands) clone is used by the majority of laboratories [38]. The signal must be interpreted with care because certain cases are marginally positive and in general the label is not as intense as the one observed for anti-ALK antibodies. It is now essential in all cases to confirm rearrangement of ROS1 by a FISH approach [45].

\subsection{Anti-EGFR Mutated Antibodies}

Different antibodies targeting a mutation in EGFR can be used on fixed tissues [33,46-52]. Nonetheless the sensitivity of these antibodies is globally lower than MB methods, in particular those for detection of deletion in exon 19, and their specificity depends on the clone and the mutation for consideration $[47,53]$. One of the advantages of IHC is the identification of a molecular target on only a few cells (as for example those visible on development of a carcinomatous lymphangitis diagnosed with a biopsy). In this situation, the extraction of DNA does not lead to a sufficient quantity of somatic DNA for detection by MB methods for mutations in EGFR (Figure 3). Aside from the limits in sensitivity and specificity the main pitfall of IHC is the limited number of activating mutations of EGFR that can be detected, which consequently may not allow treatment of patients presenting with certain mutations that are sensitive to tyrosine kinase inhibitors. Another pitfall concerns the need to perform IHC analyses on several consecutive tissue sections for detection of the L858R mutation and deletion 19 in exon 21. Finally, no commercial antibody can detect resistance mutations in EGFR including the T790M and the C797S mutations. The advantages of IHC in comparison with MB approaches include primarily the rapidity with which the results are obtained, the lower cost and the widespread development of IHC in pathology laboratories. However some new MB techniques identify the mutational status of EGFR in a few hours in one tissue section and detect a greater number of mutations, which now strongly compete with the IHC approach [54].

\subsection{Anti-BRAF Antibodies}

Depending on the published series, 1 to $6 \%$ of lung adenocarcinomas hold a mutation in the $B R A F$ gene [55-58]. Only patients with a BRAF V600E mutation are eligible for targeted treatment. Several BRAF clones for IHC have been commercialized but the VE1 clone is particularly sensitive and specific for the detection of the BRAF V600E mutation [59,60]. This clone is of interest for use now that the commercialization of therapeutic molecules for administration to patients with metastatic lung adenocarcinomas carrying the BRAF V600E mutation has been approved. The status of this mutation can thus be detected with IHC on about ten tumor cells while the MB approach can be less efficient or negative after sequencing of DNA extracted from only a few tumor cells (Figure 3). The VE1 clone can recognize epitopes present on normal human cells, in particular ciliated cells, which requires rigorous interpretation of anti-BRAF IHC on certain bronchial biopsies [61]. 


\subsection{Anti-PD-L1 Antibodies}

The development of immune check point anti-PD1/PD-L1 inhibitors has radically modified the therapeutic strategy for advanced stage or metastatic NSCLC $[62,63]$. Conversely to the other antibodies described in this paper which can be used as a screening method or as an alternative method to $\mathrm{MB}$, immunotherapy is based only on the level of expression of PD-L1 in tumor cells (Figure 4) [62]. The administration of the pembrolizumab molecule as first-line therapy to patients without genomic alterations in the genes EGFR, ALK, ROS1 and BRAF, and for whom $50 \%$ of the tumor cells express PD-L1, has given back IHC a primordial role in the therapeutic care of patients with NSCLC [63]. The development of anti-PD-L1 IHC is now done rapidly in most pathology laboratories, but all the steps require strict control [24,64-67]. The use of anti-PD-L1 IHC as a predictive biomarker for response to pembrolizumab therapy raises several questions. Many oncologists and pathologists consider this biomarker to be insufficient. In fact, some patients with a negative PD-L1 IHC show good response to immunotherapy [24,68]. In contrast, patients expressing strongly PD-L1 can show no response to anti-PD1/PD-L1 immunotherapy [24,68]. The heterogeneity in the expression of PD-L1 on IHC may be one of the reasons for these inconsistencies [69]. Moreover, PD-L1 expression varies in relation to histological patterns, with high levels in those with pleomorphic features and low expression in invasive mucinous adenocarcinomas and the lepidic components of non-mucinous adenocarcinomas [70]. In this context, evaluation of PD-L1 expression in some lung adenocarcinoma with a lepidic component may therefore be less reliable when considering immumodulatory therapy for recurrent disease. The question of which clone to use is also debatable [65,71]. So, should the kit PharmDx or LTD antibodies be used [65,66,71-75]? In this context, there are several commercially available PD-L1 IHC tests. These tests are designed by the clone used to detect the PD-L1 protein in tumor and/or immune cells. The 22C3 test (PD-L1 IHC 22C3 pharmDx, Agilent Technologies, Inc., Santa Clara, CA, USA) is currently the only test used as a companion diagnostic test (CDX) for the administration of pembrolizumab as first line treatement in advanced or metastatic NSCLC [73].

These CDX are tests with (per the US Food and Drug Administration definition) provide enough information that is essential for the safe and effective use of a corresponding drug or biologic product. Other tests such as IHC 28-8, SP142 and SP263 for nivolumab, atezolizumab and durvalumab, respectively are regarded as complementary diagnostics, but are not considered by the FDA as being essential for safe and effective treatment selection $[73,74]$.
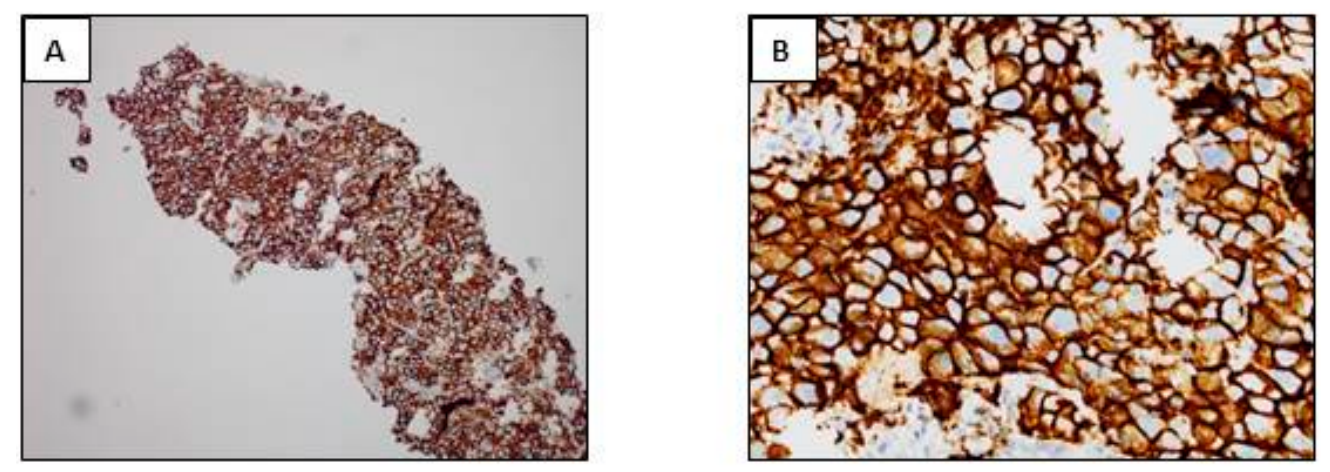

Figure 4. Cont. 

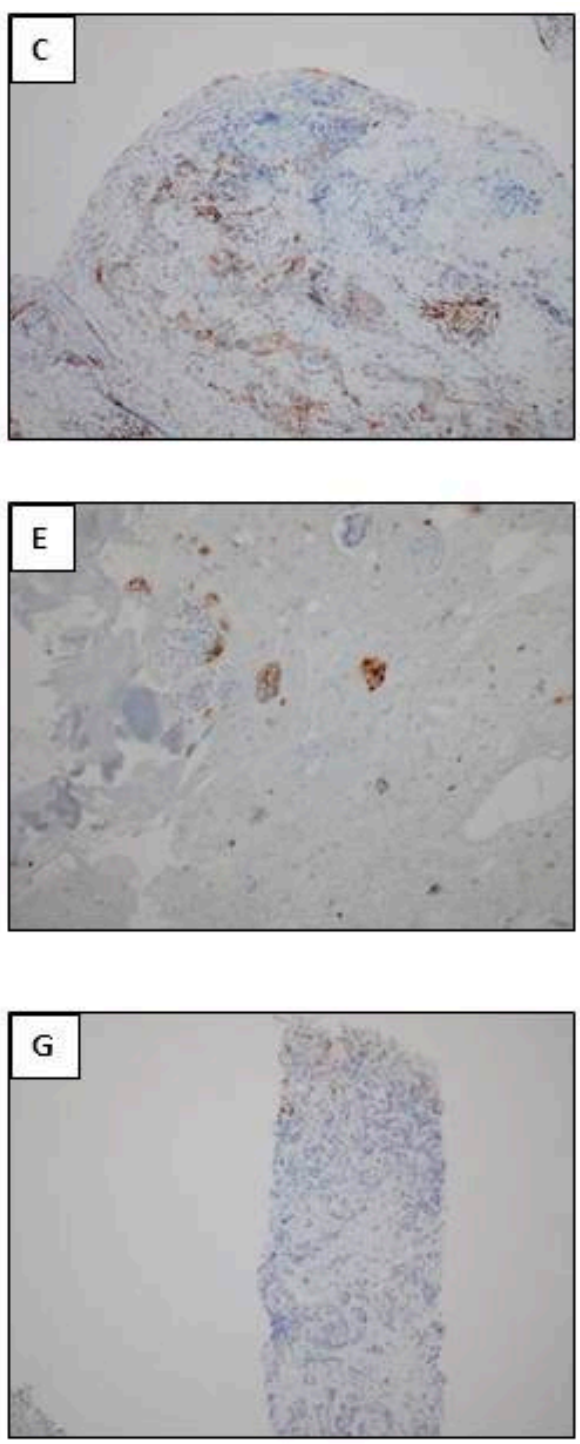
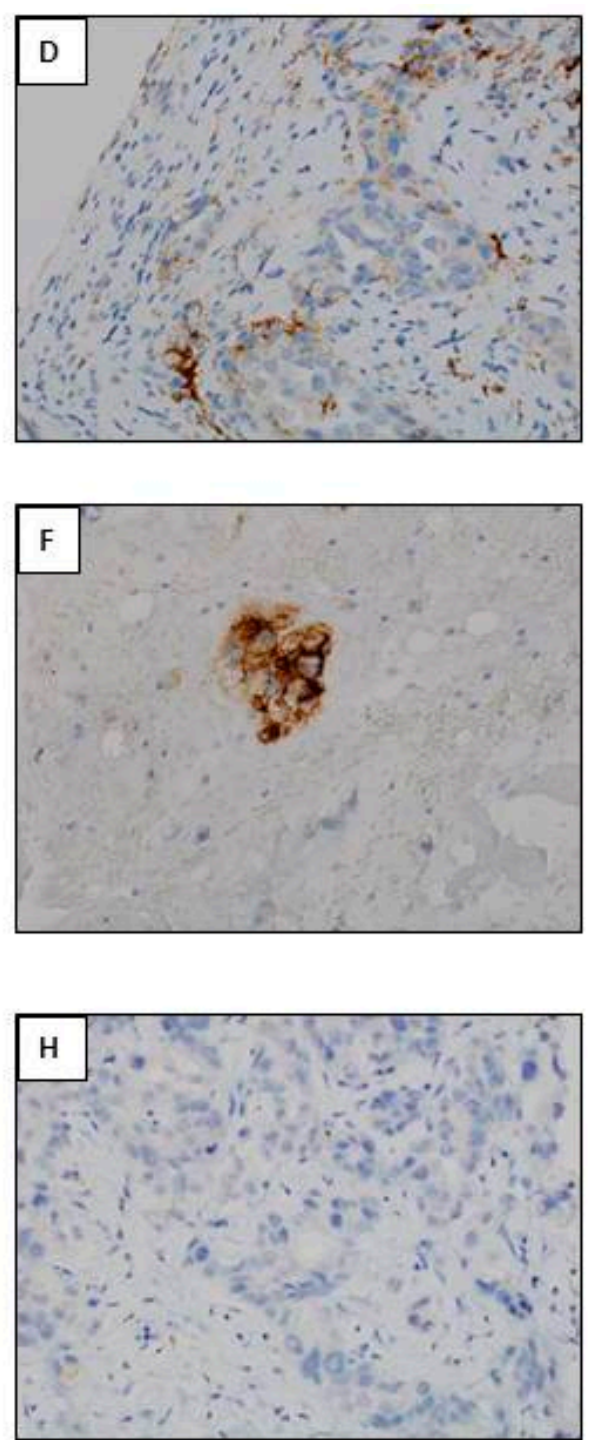

Figure 4. PD-L1 IHC (PD-L1 IHC 22C3 pharmDx, Agilent Technologies, Inc., Santa Clara, CA, USA). (A,B) Positivity of more than $50 \%$ of tumor cells. (C,D). Positivity of more than $1 \%$ and less than $50 \%$ of tumor cells. (E,F) Positivity of a few cells of a lymphangitis carcinoma. (G,H) Negative IHC. (A,C,E,G) immunoperoxisase, magnification $\times 100 ;(\mathbf{B}, \mathbf{D}, \mathbf{F}, \mathbf{H})$ immunoperoxidase, magnification $\times 400)$.

\subsection{Anti-NTRK Antibodies}

The detection of genomic alterations in NTRK has led to new therapeutic options for patients with lung cancer, in particular those with epidermoid carcinoma [76]. Anti-NTRK antibodies have been very recently developed and the expression of the protein has been shown to correlate with rearrangements in the gene [77]. Nonetheless, this molecular anomaly is very rare in NSCLC (less than $1 \%$ of patients) and so the usefulness of an IHC approach to evaluate the status of NTRK in this pathology is questionable. MB techniques, in particular next generation sequencing (NGS), can be more appropriate for detection of this rearrangement by its systematic evaluation concomitant to detection of other rearrangements in the genes ALK, ROS1, and RET [78]. However, NTRK IHC can be envisaged if only a very small number of tumor cells are visible in a biopsy and/or if the quality of the RNA proves to be inadequate for MB techniques. 


\subsection{Anti-RET Antibodies}

The RET rearrangement has been evaluated for therapeutic trials using RET inhibitors [79-81]. Correlation between mutations, amplification and over-expression of RET have given conflicting results depending on the study [81,82].

\subsection{Anti-MET Antibodies}

The expression of the protein MET has been evaluated for phase I, II and III clinical trials evaluating the administration MET inhibitors [83]. An IHC score taking into consideration the percentage of stained tumor cells and the intensity of the label was defined. While the phase II was positive, the phase III of this therapeutic trial did not confirm the results and the MET IHC did not predict the therapeutic response $[83,84]$. The majority of the published studies used the SP44 clone $[83,84]$. Depending on the study, different correlations between the protein expression, the amplification detected by FISH and the evaluation of MET mutations were obtained [85-88]. Due to these inconsistencies MET IHC is not often used currently as a predictive approach to the response to $M E T$ targeted therapy.

\subsection{Anti-ERCC1 Antibodies}

Initial studies into ERCC1 in metastatic lung epidermoid carcinomas showed good correlation between over-expression with IHC of this molecule and resistance to platinum salts [89-91]. The clone 8F1 was used [92]. Surprisingly these results were not confirmed when using the same clone [89,92]. The reason given was that the initial batch of antibody was not the same as that used subsequently and that it was impossible to reproduce the same quality of antibody. At present, ERCC1 IHC is not sufficiently robust for use as a predictive biomarker test of response to platinum salts for patients presenting with advanced stage or metastatic NSCLC [93,94].

\subsection{Anti-DLL3 Antibodies}

Until now, exceptional therapeutic trials concerning targeted therapy for SCLC were reported, given the absence of an associated biomarker for effector molecules. Treatment targeting the DLL3 molecule were recently shown to be more efficient than conventional treatment in phase I clinical trials for patients with SCLC strongly expressing the DDL3 protein on IHC [95-97].

\subsection{Other Antibodies}

A number of antibodies have been used for IHC in therapeutic trials. Thus, anti-PTEN, anti-LKB1 and anti-NRAS antibodies have been tested [98-101]. However, none of these antibodies have been used to date in the daily practice.

\section{Integration of Molecular and Immunohistochemical Approaches: What Is the Future?}

MB techniques have improved considerably in recent years. These approaches are becoming more and more sensitive and require lower and lower amounts of nucleic acids. The methods of extraction of nucleic acids have also progressed and the yield of extraction from small-sized tissue or cytological samples has led to the development of targeted molecular analyses and, in particular, NGS using formaldehyde fixed biological material. Thus, the molecular targets for personalized therapy (in particular genomic alterations in the ALK, ROS1, EGFR, BRAF, MET, HER2, NTRK, and RET genes) can be investigated and detected, either in a sequential or targeted manner or simultaneously by analysis of different panels. In this context, the role of IHC in detecting certain anomalies is debatable and indications for analysis have been and will probably be fewer and fewer in pathology laboratories. However, a number of points can be discussed:

Despite the improvement in the technologies mentioned above, MB approaches can lead to negative or uncertain results for different reasons: $(i)$ insufficient tissue, presence of necrotic areas 
and/or a low percentage of tumor cells, or a few cells will be only available for ICC (Figures 3 and 5); and (ii) alterations in the nucleic acids due to poor fixation (over-/under-fixation) or the use of an inappropriate fixation solution other than buffered $10 \%$ formol [23]. Thus, depending on the team and the techniques (in particular NGS), the percentage of tumor cells, the size and quality of the samples the recorded level of failure with bronchial or transthoracic biopsies can be up to $25 \%$ for results from $\mathrm{MB}$ approaches. However, some publications demonstrated successful library DNA preparation and sequencing in a much higher percentage of cases [17,102,103]. In a more targeted manner, the evaluation of genetic rearrangement by NGS and by RT-PCR (in particular for the $A L K$ or the ROS1 rearrangement) requires a certain amount of good quality RNA, which can be absent for small-sized bronchial biopsies that contain a small number of tumor cells or are necrotic and/or are poorly fixed [104,105]. It is probable that initial ALK IHC is more useful in evaluating the ALK status than $A L K \mathrm{MB}$ approach. This is certainly true for detection of other molecular targets from a very few cells, as for the evaluation of the BRAF V6000E mutation with IHC compared to targeted molecular analysis or extended with a NGS type of approach [106].
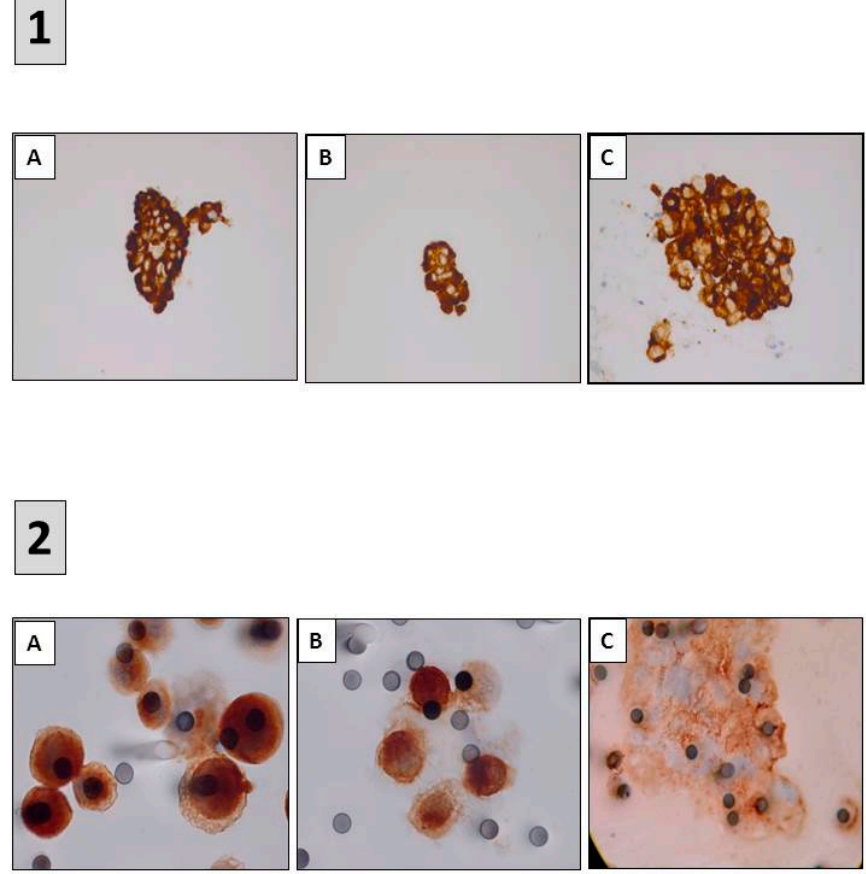

Figure 5. Detection of predictive biomarkers using immunocytochemistry (ICC). (1) ALK ICC (D5F3) (A) ROS1 ICC (D4D6) (B) and PD-L1 ICC (22C3) (C) performed on samples obtained after endobronchial ultrasound trans-bronchial needle aspirations $(\mathbf{A}-\mathbf{C})$ immunoperoxidase, magnification $\times 400$. (2) ALK ICC (D5F3) (A) MET ICC (SP44) (B) and PD-L1 ICC (22C3) (C) performed on circulating tumor cells isolated on filters after blood filtration $(A-C)$ immunoperoxidase, magnification $\times 1000$.

In certain cases, when the results must be obtained in an urgent manner, some MB approaches, in particular NGS, and to a lesser extent targeted approaches, can sometimes delay administration of effective treatment. Only certain targeted MB approaches are now able to compete with the $24 \mathrm{~h}$ required to obtain a result with $\mathrm{IHC}$ [54].

The arrival of immune-oncology and of treatment targeting PD-L1/PD1 has substantially modified the care of patients with advanced stage or metastatic NSCLC. PD-L1 IHC is performed systematically by most laboratories for administration of first-line pembrolizumab therapy, even before obtaining the results of the genetic status of EGFR, ALK, ROS1 and BRAF. Only patients without mutations in these four genes and showing expression of PD-L1 in more than 50\% of tumor cells are eligible for treatment with pembrolizumab [63]. This raises the question of whether it is preferable to evaluate 
PD-L1 by IHC on the first tissue section and to then look for genomic alterations in the four genes or the reverse, knowing that the tissue surface for analysis is diminished and that the percentage of tumor cells for IHC analysis is reduced. Moreover, in some samples, less than 100 tumor cells are detectable (Figure 4E,F). Even if these latter tumor cells are strongly stained with PD-L1 antibodies, the significance of having only few positive tumor cells is questionable since the guidelines recommend to get more than 100 tumor cells for PD-L1 assessement.

The development of novel targeted therapeutic strategies for SCLC will potentially require evaluation by MB approaches. The degraded state of DNA often obtained for this histological type of lung cancer and the small-sized biopsies usually obtained by endoscopy, render difficult MB approaches. Thus, IHC is possibly more appropriate for detection of the expression of some molecules of interest.

\section{Which Algorithms? For Which Patients? For Which Samples?}

The increase in the number of therapeutic targets for detection on smaller and smaller samples has led to the development of algorithms for use with IHC in combination with MB techniques $[8,45,107,108]$. Irrespective of the algorithm they must integrate different parameters that can be modified from case to case. The size of the sample and the percentage of tumor cells must be obtained since this information can limit the use of certain MB techniques [18]. Thus, if the sample contains only a few tumor cells IHC is the preferred approach (for example for evaluation of the $A L K$ and BRAF V600E status). Likewise, for PD-L1 IHC the first sections of small-sized biopsies should be used to examine the largest number of tumor cells possible. Ideally, a combined analysis looking for genomic alteration in EGFR, ALK, ROS1 and BRAF is indispensable, and if considered necessary, also in MET, RET, HER2, and NTRK. If several biopsies are obtained inclusion into separate paraffin blocks of each biopsy may be recommended so as to conserve sufficient tissue material for both molecular analyses and IHC. Analysis by NGS can be doomed to failure under the circumstances described above. Before performing analyses, the sequential analysis by MB and IHC for detection of a target of interest must be discussed. It is then possible to look for mutations in EGFR on tissue sections, using molecular approaches that cover the majority of mutations, and to then evaluate the status of $A L K$, then ROS1, and finally BRAF V600E by IHC. In the case of a positive ROS1 IHC, confirmation by ROS1 FISH should be performed.

These algorithms must take into account the information provided by the clinician (urgent need for the analyses, epidemiological parameters including the smoking history, age and the country of origin of the patient) $[6,109]$. In fact, it is possible that some of the collected data such as long-term exposure to tobacco and the age of the patient might limit certain analyses (in particular evaluation of a genomic modification in EGFR, ALK and ROS1 which are rarer in heavy smokers), depending on the size of the tissue sample. Finally, these algorithms and the integration of both IHC and MB approaches should take into consideration the size of the sample, the percentage of tumor cells and the quality of the material provided to the laboratory. Even if some technology, such as the Sanger method can be still use by some center, it seems that there is no longer interest to develop this approach for tissue biopsies, due to its low sensitivity. Beside "personalized medicine", we need to keep in mind that there is also probably "a personalized sample management". In this context, regardless of the algorithms that are setup in a laboratory, the surgical and molecular pathologist should take into consideration each individual sample according to the different parameters described above and quite often there is a gap between the "real life in routine practice" and some well-established algorithms.

\section{Perspectives and Conclusions}

MB and IHC are complementary for care of patients with IIIB/IV stage lung cancer. The aim of these approaches is to define the molecular targets of interest and to thus rapidly propose effective first-line treatments as alternatives to conventional chemotherapy. The administration of immunotherapy or a therapy targeting molecular anomalies is the now the priority of the thoracic oncologist. However, the tissue specimens and/or cytological samples obtained do not always allow 
evaluation of all the molecular targets and different strategies are needed depending on the case, the clinical data and the epidemiology. In addition to the evaluation of the percentage of tumor cells labeled with PD-L1 IHC, the combined development of the analysis of the tumor mutational load and the microsatellite stability status can also modify rapidly the strategy [110-112]. It would then be a question of systematically looking for molecular biomarkers taking into account the size of the sample obtained by the pathology laboratory. The development of multiplex IHC approaches offers promising prospects to better economize the biological material of interest [113-116]. Thus, it would be ideal from the onset to combine evaluation of labeling with anti-PD-L1, ALK, ROS1 and BRAFV600E antibodies on a single tissue section and then detection by MB of different mutations in EGFR on a second tissue section, except in the case of patients included in therapeutic trials. Validation of the different clones on cytological samples should be performed before potentially using multiplex approaches for ICC [22]. Discussion into MB and IHC/ICC approaches using tissues or cells should examine rapidly the adoption of the technical advances made in the detection of therapeutic targets identified with liquid biopsies from the same patients [117-119]. While the tissue biopsy approach remains the gold standard it is most likely that complementary research will be performed with blood samples, either in a simultaneous or sequential fashion, depending of the results obtained with tissues [120-122] (Figure 5). Liquid biopsy can allow to look for different genomic alterations, but also may help for the detection of different biomarkers of interest expressed on circulating tumor cells by using ICC approaches [123] (Figure 5).

Acknowledgments: The author thanks the Association de Recherche contre le Cancer (ARC), the Ligue Départementale 06 de Lutte contre le Cancer, the Conseil Départemental 06, and the Cancéropôle PACA for their support.

Conflicts of Interest: The authors declare no conflict of interest.

\section{References}

1. Hoseok, I.; Cho, J.Y. Lung Cancer Biomarkers. Adv. Clin. Chem. 2015, 72, 107-170.

2. Lewis, C.; McQuaid, S.; Hamilton, P.W.; Salto-Tellez, M.; McArt, D.; James, J.A. Building a 'Repository of Science': The importance of integrating biobanks within molecular pathology programmes. Eur. J. Cancer 2016, 67, 191-199. [CrossRef] [PubMed]

3. Oberndorfer, F.; Müllauer, L. Molecular pathology of lung cancer: Current status and perspectives. Curr. Opin. Oncol. 2017, 30, 69-76. [CrossRef] [PubMed]

4. Sholl, L. Molecular diagnostics of lung cancer in the clinic. Transl. Lung Cancer Res. 2017, 6, 560-569. [CrossRef] [PubMed]

5. Aisner, D.L.; Sholl, L.M.; Berry, L.; Rossi, M.; Chen, H.; Fujimoto, J.; Moreira, A.L.; Ramalingam, S.; Villaruz, L.C.; Otterson, G.A.; et al. The Impact of Smoking and TP53 mutations in lung adenocarcinoma patients with targetable mutations-The Lung Cancer Mutation Consortium (LCMC2). Clin. Cancer Res. 2018, 24, 1038-1047. [CrossRef] [PubMed]

6. Barlesi, F.; Mazieres, J.; Merlio, J.P.; Debieuvre, D.; Mosser, J.; Lena, H.; Ouafik, L.; Besse, B.; Rouquette, I.; Westeel, V.; et al. Biomarkers France contributors. Routine molecular profiling of patients with advanced non-small-cell lung cancer: Results of a 1-year nationwide programme of the French Cooperative Thoracic Intergroup (IFCT). Lancet 2016, 387, 1415-1426. [CrossRef]

7. Mascaux, C.; Tomasini, P.; Greillier, L.; Barlesi, F. Personalised medicine for nonsmall cell lung cancer. Eur. Respir. Rev. 2017, 26, 170066. [PubMed]

8. Osmani, L.; Askin, F.; Gabrielson, E.; Li, Q.K. Current WHO guidelines and the critical role of immunohistochemical markers in the subclassification of non-small cell lung carcinoma (NSCLC): Moving from targeted therapy to immunotherapy. Semin. Cancer Biol. 2017. [CrossRef] [PubMed]

9. Cree, I.A.; Deans, Z.; Ligtenberg, M.J.; Normanno, N.; Edsjö, A.; Rouleau, E.; Solé, F.; Thunnissen, E.; Timens, W.; Schuuring, E.; et al. European Society of Pathology Task Force on Quality Assurance in Molecular Pathology; Royal College of Pathologists. Guidance for laboratories performing molecular pathology for cancer patients. J. Clin. Pathol. 2014, 67, 923-931. [CrossRef] [PubMed] 
10. James, D.; Ames, D.; Lopez, B.; Still, R.; Simpson, W.; Twomey, P. External quality assessment: Best practice. J. Clin. Pathol. 2014, 67, 651-655. [CrossRef] [PubMed]

11. Tembuyser, L.; Dequeker, E.M. Endorsing good quality assurance practices in molecular pathology: Risks and recommendations for diagnostic laboratories and external quality assessment providers. Virchows Arch. 2016, 468, 31-41. [CrossRef] [PubMed]

12. Vermaelen, K.; Waeytens, A.; Kholmanskikh, O.; van den Bulcke, M.; van Valckenborgh, E. Perspectives on the integration of Immuno-Oncology Biomarkers and drugs in a Health Care setting. Semin. Cancer Biol. 2017. [CrossRef] [PubMed]

13. Dhillon, S.S.; Harris, K. Bronchoscopy for the diagnosis of peripheral lung lesions. J. Thorac. Dis. 2017, 9, S1047-S1058. [CrossRef] [PubMed]

14. Labarca, G.; Aravena, C.; Ortega, F.; Arenas, A.; Majid, A.; Folch, E.; Mehta, H.J.; Jantz, M.A.; Fernandez-Bussy, S. Minimally invasive methods for staging in lung cancer: Systematic review and meta-analysis. Pulm. Med. 2016, 2016, 1024709. [CrossRef] [PubMed]

15. Mudambi, L.; Ost, D.E. Advanced bronchoscopic techniques for the diagnosis of peripheral pulmonary lesions. Curr. Opin. Pulm. Med. 2016, 22, 309-318. [CrossRef] [PubMed]

16. Shepherd, R.W. Bronchoscopic pursuit of the peripheral pulmonary lesion: Navigational bronchoscopy, radial endobronchial ultrasound, and ultrathin bronchoscopy. Curr. Opin. Pulm. Med. 2016, 22, 257-264. [CrossRef] [PubMed]

17. Bubendorf, L.; Lantuejoul, S.; de Langen, A.J.; Thunnissen, E. Nonsmall cell lung carcinoma: Diagnostic difficulties in small biopsies and cytological specimens: Number 2 in the Series "Pathology for the clinician" Edited by Peter Dorfmüller and Alberto Cavazza. Eur. Respir. Rev. 2017, 26, 170007. [CrossRef] [PubMed]

18. Long, É; Ilie, M.; Hofman, V.; Lassalle, S.; Butori, C.; Alsubaie, S.; Hofman, P. Role of the surgical pathologist for tissue management in oncology. Bull. Cancer 2013, 100, 837-845. [PubMed]

19. Bussolati, G.; Annaratone, L.; Maletta, F. The pre-analytical phase in surgical pathology. Recent Results Cancer Res. 2015, 199, 1-13. [PubMed]

20. Hofman, V.; Ilie, M.; Gavric-Tanga, V.; Lespinet, V.; Mari, M.; Lassalle, S.; Butori, C.; Coelle, C.; Bordone, O.; Selva, E.; et al. Role of the surgical pathology laboratory in the pre-analytical approach of molecular biology techniques. Ann. Pathol. 2010, 30, 85-93. [CrossRef] [PubMed]

21. Engel, K.B.; Moore, H.M. Effects of preanalytical variables on the detection of proteins by immunohistochemistry in formalin-fixed, paraffin-embedded tissue. Arch. Pathol. Lab. Med. 2011, 135, 537-543. [PubMed]

22. Roy-Chowdhuri, S.; Aisner, D.L.; Allen, T.C.; Beasley, M.B.; Borczuk, A.; Cagle, P.T.; Capelozzi, V.; Dacic, S.; da Cunha Santos, G.; Hariri, L.P.; et al. Biomarker Testing in Lung Carcinoma Cytology Specimens: A Perspective From Members of the Pulmonary Pathology Society. Arch. Pathol. Lab. Med. 2016, 140, 1267-1272. [CrossRef] [PubMed]

23. Ilie, M.; Hofman, P. Pitfalls in lung cancer molecular pathology: How to limit them in routine practice? Curr. Med. Chem. 2012, 19, 2638-2651. [CrossRef] [PubMed]

24. Dong, Z.; Li, H.; Zhou, J.; Zhang, W.; Wu, C. The value of cell block based on fine needle aspiration for lung cancer diagnosis. J. Thorac. Dis. 2017, 9, 2375-2382. [CrossRef] [PubMed]

25. Ilie, M.; Juco, J.; Huang, L.; Hofman, V.; Khambata-Ford, S.; Hofman, P. Use of the 22C3 anti-programmed death ligand 1 antibody to determine programmed death ligand 1 expression in cytology samples obtained from non-small cell lung cancer patients. Cancer Cytopathol. 2018. [CrossRef] [PubMed]

26. Russell-Goldman, E.; Kravets, S.; Dahlberg, S.E.; Sholl, L.M.; Vivero, M. Cytologic-histologic correlation of programmed death-ligand 1 immunohistochemistry in lung carcinomas. Cancer Cytopathol. 2018. [CrossRef] [PubMed]

27. Zhou, J.; Yao, H.; Zhao, J.; Zhang, S.; You, Q.; Sun, K.; Zou, Y.; Zhou, C.; Zhou, J. Cell block samples from malignant pleural effusion might be valid alternative samples for anaplastic lymphoma kinase detection in patients with advanced non-small-cell lung cancer. Histopathology 2015, 66, 949-954. [CrossRef] [PubMed]

28. Hofman, P. PD-L1 immunohistochemistry for non-small cell lung carcinoma: Which strategy should be adopted? Expert Rev. Mol. Diagn. 2017. [CrossRef] [PubMed]

29. Zhiwei, W.; Yuan, J.; Yihui, Y.; Xin, H.; Jingtao, C.; Lei, S.; Yongjian, D. Ventana immunohistochemistry assay for anaplastic lymphoma kinase gene rearrangement detection in patients with non-small cell lung cancer: A meta-analysis. Thorac. Cancer 2017, 8, 471-476. [CrossRef] [PubMed] 
30. Conde, E.; Hernandez, S.; Prieto, M.; Martinez, R.; Lopez-Rios, F. Profile of Ventana ALK (D5F3) companion diagnostic assay for non-small-cell lung carcinomas. Expert Rev. Mol. Diagn. 2016, 16, 707-713. [CrossRef] [PubMed]

31. Thorne-Nuzzo, T.; Williams, C.; Catallini, A.; Clements, J.; Singh, S.; Amberson, J.; Dickinson, K.; Gatalica, Z.; Ho, S.N.; Loftin, I.; et al. A Sensitive ALK Immunohistochemistry Companion Diagnostic Test Identifies Patients Eligible for Treatment with Crizotinib. J. Thorac. Oncol. 2017, 12, 804-813. [CrossRef] [PubMed]

32. Vinciguerra, G.L.R.; Scarpino, S.; Pini, B.; Cippitelli, C.; Fochetti, F.; Ruco, L. Optimized immunohistochemistry using the D5F3 antibody provides a reliable test for identification of ALK-positive lung adenocarcinomas. Virchows Arch. 2017, 47, 123-127. [CrossRef] [PubMed]

33. Hofman, P.; Ilie, M.; Hofman, V.; Roux, S.; Valent, A.; Bernheim, A.; Alifano, M.; Leroy-Ladurie, F.; Vaylet, F.; Rouquette, I.; et al. Immunohistochemistry to identify EGFR mutations or ALK rearrangements in patients with lung adenocarcinoma. Ann. Oncol. 2012, 23, 1738-1743. [CrossRef] [PubMed]

34. Von Laffert, M.; Schirmacher, P.; Warth, A.; Weichert, W.; Büttner, R.; Huber, R.M.; Wolf, J.; Griesinger, F.; Dietel, M.; Grohé, C. ALK-Testing in non-small cell lung cancer (NSCLC): Immunohistochemistry (IHC) and/or fluorescence in-situ Hybridisation (FISH)?: Statement of the Germany Society for Pathology (DGP) and the Working Group Thoracic Oncology (AIO) of the German Cancer Society e.V. (Stellungnahme der Deutschen Gesellschaft für Pathologie und der AG Thorakale Onkologie der Arbeitsgemeinschaft Onkologie/Deutsche Krebsgesellschaft e.V.). Lung Cancer 2017, 103, 1-5. [PubMed]

35. Ibrahim, M.; Parry, S.; Wilkinson, D.; Bilbe, N.; Allen, D.; Forrest, S.; Maxwell, P.; O'Grady, A.; Starczynski, J.; Tanier, P.; et al. ALK Immunohistochemistry in NSCLC: Discordant staining can impact patient treatment regimen. J. Thorac. Oncol. 2016, 11, 2241-2247. [CrossRef] [PubMed]

36. Ilie, M.I.; Bence, C.; Hofman, V.; Long-Mira, E.; Butori, C.; Bouhlel, L.; Lalvée, S.; Mouroux, J.; Poudenx, M.; Otto, J.; et al. Discrepancies between FISH and immunohistochemistry for assessment of the ALK status are associated with ALK 'borderline'-positive rearrangements or a high copy number: A potential major issue for anti-ALK therapeutic strategies. Ann. Oncol. 2015, 26, 238-244. [CrossRef] [PubMed]

37. Rosoux, A.; Pauwels, P.; Duplaquet, F.; D’Haene, N.; Weynand, B.; Delos, M.; Menon, R.; Heukamp, L.C.; Thunnissen, E.; Ocak, S. Effectiveness of crizotinib in a patient with ALK IHC-positive/FISH-negative metastatic lung adenocarcinoma. Lung Cancer 2016, 98, 118-121. [CrossRef] [PubMed]

38. Trejo Bittar, H.E.; Luvison, A.; Miller, C.; Dacic, S. A comparison of ALK gene rearrangement and ALK protein expression in primary lung carcinoma and matched metastasis. Histopathology 2017, 71, 269-277. [CrossRef] [PubMed]

39. Rosenblum, F.; Hutchinson, L.M.; Garver, J.; Woda, B.; Cosar, E.; Kurian, E.M. Cytology specimens offer an effective alternative to formalin-fixed tissue as demonstrated by novel automated detection for ALK break-apart FISH testing and immunohistochemistry in lung adenocarcinoma. Cancer Cytopathol. 2014, 122, 810-821. [CrossRef] [PubMed]

40. Pisapia, P.; Lozano, M.D.; Vigliar, E.; Bellevicine, C.; Pepe, F.; Malapelle, U.; Troncone, G. ALK and ROS1 testing on lung cancer cytologic samples: Perspectives. Cancer Cytopathol. 2017, 125, 817-830. [CrossRef] [PubMed]

41. Bubendorf, L.; Büttner, R.; Al-Dayel, F.; Dietel, M.; Elmberger, G.; Kerr, K.; López-Ríos, F.; Marchetti, A.; Öz, B.; Pauwels, P.; et al. Testing for ROS1 in non-small cell lung cancer: A review with recommendations. Virchows Arch. 2016, 469, 489-503. [CrossRef] [PubMed]

42. Pal, P.; Khan, Z. ROS1-1. J. Clin. Pathol. 2017, 70, 1001-1009. [CrossRef] [PubMed]

43. Su, Y.; Goncalves, T.; Dias-Santagata, D.; Hoang, M.P. Immunohistochemical Detection of ROS1 Fusion. Am. J. Clin. Pathol. 2017, 147, 77-82. [PubMed]

44. Viola, P.; Maurya, M.; Croud, J.; Gazdova, J.; Suleman, N.; Lim, E.; Newsom-Davis, T.; Plowman, N.; Rice, A.; Montero, M.A.; et al. A Validation Study for the Use of ROS1 Immunohistochemical Staining in Screening for ROS1 Translocations in Lung Cancer. J. Thorac. Oncol. 2016, 11, 1029-1039. [CrossRef] [PubMed]

45. Selinger, C.I.; Li, B.T.; Pavlakis, N.; Links, M.; Gill, A.J.; Lee, A.; Clarke, S.; Tran, T.N.; Lum, T.; Yip, P.Y.; et al. Screening for ROS1 gene rearrangements in non-small-cell lung cancers using immunohistochemistry with FISH confirmation is an effective method to identify this rare target. Histopathology 2017, 70, 402-411. [CrossRef] [PubMed] 
46. Allo, G.; Bandarchi, B.; Yanagawa, N.; Wang, A.; Shih, W.; Xu, J.; Dalby, M.; Nitta, H.; To, C.; Liu, N.; et al. Epidermal growth factor receptor mutation-specific immunohistochemical antibodies in lung adenocarcinoma. Histopathology 2014, 64, 826-839. [CrossRef] [PubMed]

47. Bondgaard, A.L.; Høgdall, E.; Mellemgaard, A.; Skov, B.G. High specificity but low sensitivity of mutation-specific antibodies against EGFR mutations in non-small-cell lung cancer. Mod. Pathol. 2014, 27, 1590-1598. [CrossRef] [PubMed]

48. Fan, X.; Liu, B.; Xu, H.; Yu, B.; Shi, S.; Zhang, J.; Wang, X.; Wang, J.; Lu, Z.; Ma, H.; et al. Immunostaining with EGFR mutation-specific antibodies: A reliable screening method for lung adenocarcinomas harboring EGFR mutation in biopsy and resection samples. Hum. Pathol. 2013, 44, 1499-1507. [CrossRef] [PubMed]

49. Houang, M.; Sioson, L.; Clarkson, A.; Watson, N.; Farzin, M.; Toon, C.W.; Raut, A.; O'Toole, S.A.; Cooper, W.A.; Pavlakis, N.; et al. EGFR mutation specific immunohistochemistry is a useful adjunct which helps to identify false negative mutation testing in lung cancer. Pathology 2014, 46, 501-508. [CrossRef] [PubMed]

50. Kim, C.H.; Kim, S.H.; Park, S.Y.; Yoo, J.; Kim, S.K.; Kim, H.K. Identification of EGFR Mutations by Immunohistochemistry with EGFR Mutation-Specific Antibodies in Biopsy and Resection Specimens from Pulmonary Adenocarcinoma. Cancer Res. Treat. 2015, 47, 653-660. [CrossRef] [PubMed]

51. Seo, A.N.; Park, T.I.; Jin, Y.; Sun, P.L.; Kim, H.; Chang, H.; Chung, J.H. Novel EGFR mutation-specific antibodies for lung adenocarcinoma: Highly specific but not sensitive detection of an E746_A750 deletion in exon 19 and an L858R mutation in exon 21 by immunohistochemistry. Lung Cancer 2014, 83, 316-323. [CrossRef] [PubMed]

52. Wen, Y.H.; Brogi, E.; Hasanovic, A.; Ladanyi, M.; Soslow, R.A.; Chitale, D.; Shia, J.; Moreira, A.L. Immunohistochemical staining with EGFR mutation-specific antibodies: High specificity as a diagnostic marker for lung adenocarcinoma. Mod. Pathol. 2013, 26, 1197-1203. [CrossRef] [PubMed]

53. Verdu, M.; Trias, I.; Roman, R.; Rodon, N.; Pubill, C.; Arraiza, N.; Martinez, B.; Garcia-Pelaez, B.; Serrano, T.; Puig, X. Cross-reactivity of EGFR mutation-specific immunohistochemistry assay in HER2-positive tumors. Appl. Immunohistochem. Mol. Morphol. 2015, 23, 565-570. [CrossRef] [PubMed]

54. Ilie, M.; Butori, C.; Lassalle, S.; Heeke, S.; Piton, N.; Sabourin, J.C.; Tanga, V.; Washetine, K.; Long-Mira, E.; Maitre, P.; et al. Optimization of EGFR mutation detection by the fully-automated qPCR-based Idylla system on tumor tissue from patients with non-small cell lung cancer. Oncotarget 2017, 8, 103055-103062. [CrossRef] [PubMed]

55. Kinno, T.; Tsuta, K.; Shiraishi, K.; Mizukami, T.; Suzuki, M.; Yoshida, A.; Suzuki, K.; Asamura, H.; Furuta, K.; Kohno, T.; et al. Clinicopathological features of nonsmall cell lung carcinomas with BRAF mutations. Ann. Oncol. 2014, 25, 138-142. [CrossRef] [PubMed]

56. Luk, P.P.; Yu, B.; Ng, C.C.; Mercorella, B.; Selinger, C.; Lum, T.; Kao, S.; O’Toole, S.A.; Cooper, W.A. BRAF mutations in non-small cell lung cancer. Transl. Lung Cancer Res. 2015, 4, 142-148. [PubMed]

57. Marchetti, A.; Felicioni, L.; Malatesta, S.; Grazia Sciarrotta, M.; Guetti, L.; Chella, A.; Viola, P.; Pullara, C.; Mucilli, F.; Buttitta, F. Clinical features and outcome of patients with non-small-cell lung cancer harboring BRAF mutations. J. Clin. Oncol. 2011, 29, 3574-3579. [CrossRef] [PubMed]

58. Tissot, C.; Couraud, S.; Tanguy, R.; Bringuier, P.P.; Girard, N.; Souquet, P.J. Clinical characteristics and outcome of patients with lung cancer harboring BRAF mutations. Lung Cancer 2016, 91, 23-28. [CrossRef] [PubMed]

59. Ilie, M.; Long, E.; Hofman, V.; Dadone, B.; Marquette, C.H.; Mouroux, J.; Vignaud, J.M.; Begueret, H.; Merlio, J.P.; Capper, D.; et al. Diagnostic value of immunohistochemistry for the detection of the BRAFV600E mutation in primary lung adenocarcinoma Caucasian patients. Ann. Oncol. 2013, 24, 742-748. [CrossRef] [PubMed]

60. Ritterhouse, L.L.; Barletta, J.A. BRAF V600E mutation-specific antibody: A review. Semin. Diagn. Pathol. 2015, 32, 400-408. [CrossRef] [PubMed]

61. Jones, R.T.; Abedalthagafi, M.S.; Brahmandam, M.; Greenfield, E.A.; Hoang, M.P.; Louis, D.N.; Hornick, J.L.; Santagata, S. Cross-reactivity of the BRAF VE1 antibody with epitopes in axonemal dyneins leads to staining of cilia. Mod. Pathol. 2015, 28, 596-606. [CrossRef] [PubMed]

62. Ilie, M.; Hofman, P. Immunotherapy supplanting chemotherapy for upfront treatment of advanced non-small cell lung cancer: What's next? J. Thorac. Dis. 2017, 9, E519-E521. [CrossRef] [PubMed]

63. Reck, M. Pembrolizumab as first-line therapy for metastatic non-small-cell lung cancer. Immunotherapy 2018, 10, 93-105. [CrossRef] [PubMed] 
64. Cree, I.A.; Booton, R.; Cane, P.; Gosney, J.; Ibrahim, M.; Kerr, K.; Lal, R.; Lewanski, C.; Navani, N.; Nicholson, A.G.; et al. PD-L1 testing for lung cancer in the UK: Recognizing the challenges for implementation. Histopathology 2016, 69, 177-186. [CrossRef] [PubMed]

65. Ilie, M.; Hofman, V.; Dietel, M.; Soria, J.C.; Hofman, P. Assessment of the PD-L1 status by immunohistochemistry: Challenges and perspectives for therapeutic strategies in lung cancer patients. Virchows Arch. 2016, 468, 511-525. [CrossRef] [PubMed]

66. Thunnissen, E.; de Langen, A.J.; Smit, E.F. PD-L1 IHC in NSCLC with a global and methodological perspective. Lung Cancer 2017, 113, 102-105. [CrossRef] [PubMed]

67. Yu, H.; Boyle, T.A.; Zhou, C.; Rimm, D.L.; Hirsch, F.R. PD-L1 Expression in Lung Cancer. J. Thorac. Oncol. 2016, 11, 964-975. [CrossRef] [PubMed]

68. Chae, Y.K.; Pan, A.; Davis, A.A.; Raparia, K.; Mohindra, N.A.; Matsangou, M.; Giles, F.J. Biomarkers for PD-1/PD-L1 Blockade Therapy in Non-Small-cell Lung Cancer: Is PD-L1 Expression a Good Marker for Patient Selection? Clin. Lung Cancer 2016, 17, 350-361. [CrossRef] [PubMed]

69. Ilie, M.; Long-Mira, E.; Bence, C.; Butori, C.; Lassalle, S.; Bouhlel, L.; Fazzalari, L.; Zahaf, K.; Lalvée, S.; Washetine, K.; et al. Comparative study of the PD-L1 status between surgically resected specimens and matched biopsies of NSCLC patients reveal major discordances: A potential issue for anti-PD-L1 therapeutic strategies. Ann. Oncol. 2016, 27, 147-153. [CrossRef] [PubMed]

70. Ng Kee Kwong, F.; Laggner, U.; Mc Kinney, O.; Croud, J.; Rice, A.; Nicholson, A.G. Expression of PD-L1 correlates with pleomorphic morphology and histological patterns of non-small cell lung carcinomas. Histopathology 2018. [CrossRef] [PubMed]

71. Kerr, K.M.; Nicolson, M.C. Non-Small Cell Lung Cancer, PD-L1, and the Pathologist. Arch. Pathol. Lab. Med. 2016, 140, 249-254. [CrossRef] [PubMed]

72. Adam, J.; Le Stang, N.; Rouquette, I.; Cazes, A.; Badoual, C.; Pinot-Roussel, H.; Tixier, L.; Danel, C.; Damiola, F.; Damotte, D.; et al. Multicenter French harmonization study for PD-L1 IHC testing in non-small cell lung cancer. Ann. Oncol. 2018. [CrossRef] [PubMed]

73. Brody, R.; Zhang, Y.; Ballas, M.; Siddiqui, M.K.; Gupta, P.; Barker, C.; Midha, A.; Walker, J. PD-L1 expression in advanced NSCLC: Insights into risk stratification and treatment selection from a systematic literature review. Lung Cancer 2017, 112, 200-215. [CrossRef] [PubMed]

74. Hendry, S.; Byrne, D.J.; Wright, G.M.; Young, R.J.; Sturrock, S.; Cooper, W.A.; Fox, S.B. Comparison of Four PD-L1 Immunohistochemical Assays in Lung Cancer. J. Thorac. Oncol. 2018, 13, 367-376. [CrossRef] [PubMed]

75. Ilie, M.; Khambata-Ford, S.; Copie-Bergman, C.; Huang, L.; Juco, J.; Hofman, V.; Hofman, P. Use of the 22C3 anti-PD-L1 antibody to determine PD-L1 expression in multiple automated immunohistochemistry platforms. PLoS ONE 2017, 12, e0183023.

76. Rolfo, C.; Raez, L. New targets bring hope in squamous cell lung cancer: Neurotrophic tyrosine kinase gene fusions. Lab. Investig. 2017, 97, 1268-1270. [CrossRef] [PubMed]

77. Hechtman, J.F.; Benayed, R.; Hyman, D.M.; Drilon, A.; Zehir, A.; Frosina, D.; Arcila, M.E.; Dogan, S.; Klimstra, D.S.; Ladanyi, M.; et al. Pan-Trk Immunohistochemistry Is an Efficient and Reliable Screen for the Detection of NTRK Fusions. Am. J. Surg. Pathol. 2017, 41, 1547-1551. [CrossRef] [PubMed]

78. Farago, A.F.; Azzoli, C.G. Beyond ALK and ROS1: RET, NTRK, EGFR and BRAF gene rearrangements in non-small cell lung cancer. Transl. Lung Cancer Res. 2017, 6, 550-559. [CrossRef] [PubMed]

79. Ferrara, R.; Auger, N.; Auclin, E.; Besse, B. Clinical and translational implications of RET rearrangements in non-small cell lung cancer. J. Thorac. Oncol. 2018, 13, 27-45. [CrossRef] [PubMed]

80. Gautschi, O.; Milia, J.; Filleron, T.; Wolf, J.; Carbone, D.P.; Owen, D.; Camidge, R.; Narayanan, V.; Doebele, R.C.; Besse, B.; et al. Targeting RET in patients with RET-rearranged lung cancers: Results from the global, multicenter RET registry. J. Clin. Oncol. 2017, 35, 1403-1410. [CrossRef] [PubMed]

81. Platt, A.; Morten, J.; Ji, Q.; Elvin, P.; Womack, C.; Su, X.; Donald, E.; Gray, N.; Read, J.; Bigley, G.; et al. A retrospective analysis of RET translocation, gene copy number gain and expression in NSCLC patients treated with vandetanib in four randomized Phase III studies. BMC Cancer 2015, 15, 171. [CrossRef] [PubMed]

82. Lee, S.E.; Lee, B.; Hong, M.; Song, J.Y.; Jung, K.; Lira, M.E.; Mao, M.; Han, J.; Kim, J.; Choi, Y.L. Comprehensive analysis of RET and ROS1 rearrangement in lung adenocarcinoma. Mod. Pathol. 2015, 28, 468-479. [CrossRef] [PubMed] 
83. Koeppen, H.; Yu, W.; Zha, J.; Pandita, A.; Penuel, E.; Rangell, L.; Raja, R.; Mohan, S.; Patel, R.; Desai, R.; et al. Biomarker analyses from a placebo-controlled phase II study evaluating erlotinib \pm onartuzumab in advanced non-small cell lung cancer: MET expression levels are predictive of patient benefit. Clin. Cancer Res. 2014, 20, 4488-4498. [CrossRef] [PubMed]

84. Spigel, D.R.; Edelman, M.J.; O’Byrne, K.; Paz-Ares, L.; Mocci, S.; Phan, S.; Shames, D.S.; Smith, D.; Yu, W.; Paton, V.E.; et al. Results from the Phase III Randomized Trial of Onartuzumab Plus Erlotinib Versus Erlotinib in Previously Treated Stage IIIB or IV Non-Small-Cell Lung Cancer: METLung. J. Clin. Oncol. 2017, 35, 412-420. [CrossRef] [PubMed]

85. Park, S.; Koh, J.; Kim, D.W.; Kim, M.; Keam, B.; Kim, T.M.; Jeon, Y.K.; Chung, D.H.; Heo, D.S. MET amplification, protein expression, and mutations in pulmonary adenocarcinoma. Lung Cancer 2015, 90, 381-387. [CrossRef] [PubMed]

86. Sterlacci, W.; Fiegl, M.; Gugger, M.; Bubendorf, L.; Savic, S.; Tzankov, A. MET overexpression and gene amplification: Prevalence, clinico-pathological characteristics and prognostic significance in a large cohort of patients with surgically resected NSCLC. Virchows Arch. 2017, 471, 49-55. [CrossRef] [PubMed]

87. Watermann, I.; Schmitt, B.; Stellmacher, F.; Müller, J.; Gaber, R.; Kugler, C.H.; Reinmuth, N.; Huber, R.M.; Thomas, M.; Zabel, P.; et al. Improved diagnostics targeting c-MET in non-small cell lung cancer: Expression, amplification and activation? Diagn. Pathol. 2015, 10, 130. [CrossRef] [PubMed]

88. Weingertner, N.; Meyer, N.; Voegeli, A.C.; Guenot, D.; Renaud, S.; Massard, G.; Falcoz, P.E.; Olland, A.; Mennecier, B.; Gaub, M.P.; et al. Correlation between MET protein expression and MET gene copy number in a Caucasian cohort of non-small cell lung cancers according to the new IASLC/ATS/ERS classification. Pathology 2015, 47, 320-328. [CrossRef] [PubMed]

89. Friboulet, L.; Olaussen, K.A.; Pignon, J.P.; Shepherd, F.A.; Tsao, M.S.; Graziano, S.; Kratzke, R.; Douillard, J.Y.; Seymour, L.; Pirker, R.; et al. ERCC1 isoform expression and DNA repair in non-small-cell lung cancer. N. Engl. J. Med. 2013, 368, 1101-1110. [CrossRef] [PubMed]

90. Olaussen, K.A.; Dunant, A.; Fouret, P.; Brambilla, E.; André, F.; Haddad, V.; Taranchon, E.; Filipits, M.; Pirker, R.; Popper, H.H.; et al. IALT Bio Investigators. DNA repair by ERCC1 in non-small-cell lung cancer and cisplatin-based adjuvant chemotherapy. N. Engl. J. Med. 2006, 355, 983-991. [CrossRef] [PubMed]

91. Pierceall, W.E.; Olaussen, K.A.; Rousseau, V.; Brambilla, E.; Sprott, K.M.; Andre, F.; Pignon, J.P.; Le Chevalier, T.; Pirker, R.; Jiang, C.; et al. Cisplatin benefit is predicted by immunohistochemical analysis of DNA repair proteins in squamous cell carcinoma but not adenocarcinoma: Theranostic modeling by NSCLC constituent histological subclasses. Ann. Oncol. 2012, 23, 2245-2252. [CrossRef] [PubMed]

92. Handra-Luca, A.; Hernandez, J.; Mountzios, G.; Taranchon, E.; Lacau-St-Guily, J.; Soria, J.C.; Fouret, P. Excision repair cross complementation group 1 immunohistochemical expression predicts objective response and cancer-specific survival in patients treated by Cisplatin-based induction chemotherapy for locally advanced head and neck squamous cell carcinoma. Clin. Cancer Res. 2007, 13, 3855-3859. [CrossRef] [PubMed]

93. Lee, S.M.; Falzon, M.; Blackhall, F.; Spicer, J.; Nicolson, M.; Chaudhuri, A.; Middleton, G.; Ahmed, S.; Hicks, J.; Crosse, B.; et al. Randomized prospective biomarker trial of ERCC1 for comparing platinum and nonplatinum therapy in advanced non-small-cell lung cancer: ERCC1 Trial (ET). J. Clin. Oncol. 2017, 35, 402-411. [CrossRef] [PubMed]

94. Postel-Vinay, S.; Soria, J.C. ERCC1 as predictor of platinum benefit in Non-Small-Cell Lung Cancer. J. Clin. Oncol. 2017, 35, 384-386. [CrossRef] [PubMed]

95. Cardnell, R.J.; Li, L.; Sen, T.; Bara, R.; Tong, P.; Fujimoto, J.; Ireland, A.S.; Guthrie, M.R.; Bheddah, S.; Banerjee, U.; et al. Protein expression of TTF1 and cMYC define distinct molecular subgroups of small cell lung cancer with unique vulnerabilities to aurora kinase inhibition, DLL3 targeting, and other targeted therapies. Oncotarget 2017, 8, 73419-73432. [CrossRef] [PubMed]

96. Rudin, C.M.; Pietanza, M.C.; Bauer, T.M.; Ready, N.; Morgensztern, D.; Glisson, B.S.; Byers, L.A.; Johnson, M.L.; Burris, H.A., 3rd; Robert, F.; et al. SCRX16-001 investigators. Rovalpituzumab tesirine, a DLL3-targeted antibody-drug conjugate, in recurrent small-cell lung cancer: A first-in-human, first-in-class, open-label, phase 1 study. Lancet Oncol. 2017, 18, 42-51. [CrossRef]

97. Sharma, S.K.; Pourat, J.; Abdel-Atti, D.; Carlin, S.D.; Piersigilli, A.; Bankovich, A.J.; Gardner, E.E.; Hamdy, O.; Isse, K.; Bheddah, S.; et al. Noninvasive Interrogation of DLL3 expression in metastatic small cell lung cancer. Cancer Res. 2017, 77, 3931-3941. [CrossRef] [PubMed] 
98. Calles, A.; Sholl, L.M.; Rodig, S.J.; Pelton, A.K.; Hornick, J.L.; Butaney, M.; Lydon, C.; Dahlberg, S.E.; Oxnard, G.R.; Jackman, D.M.; et al. Immunohistochemical loss of LKB1 is a biomarker for more aggressive biology in KRAS-mutant lung adenocarcinoma. Clin. Cancer Res. 2015, 21, 2851-2860. [CrossRef] [PubMed]

99. Cumberbatch, M.; Tang, X.; Beran, G.; Eckersley, S.; Wang, X.; Ellston, R.P.; Dearden, S.; Cosulich, S.; Smith, P.D.; Behrens, C.; et al. Identification of a subset of human non-small cell lung cancer patients with high PI3K $\beta$ and low PTEN expression, more prevalent in squamous cell carcinoma. Clin. Cancer Res. 2014, 20, 595-603. [CrossRef] [PubMed]

100. Ilie, M.; Long-Mira, E.; Funck-Brentano, E.; Lassalle, S.; Butori, C.; Lespinet-Fabre, V.; Bordone, O.; Gay, A.; Zahaf, K.; Poissonnet, G.; et al. Immunohistochemistry as a potential tool for routine detection of the NRAS Q61R mutation in patients with metastatic melanoma. J. Am. Acad. Dermatol. 2015, 72, 786-793. [CrossRef] [PubMed]

101. Shin, E.; Choi, C.M.; Kim, H.R.; Jang, S.J.; Park, Y.S. Immunohistochemical characterization of the mTOR pathway in stage-I non-small-cell lung carcinoma. Lung Cancer 2015, 89, 13-18. [CrossRef] [PubMed]

102. Padmanabhan, V.; Steinmetz, H.B.; Rizzo, E.J.; Erskine, A.J.; Fairbank, T.L.; de Abreu, F.B.; Tsongalis, G.J.; Tafe, L.J. Improving Adequacy of Small Biopsy and Fine-Needle Aspiration Specimens for Molecular Testing by Next-Generation Sequencing in Patients with Lung Cancer: A Quality Improvement Study at Dartmouth-Hitchcock Medical Center. Arch. Pathol. Lab. Med. 2017, 141, 402-409. [CrossRef] [PubMed]

103. Tafe, L.J.; Pierce, K.J.; Peterson, J.D.; de Abreu, F.; Memoli, V.A.; Black, C.C.; Pettus, J.R.; Marotti, J.D.; Gutmann, E.J.; Liu, X.; et al. Clinical Genotyping of Non-Small Cell Lung Cancers Using Targeted Next-Generation Sequencing: Utility of Identifying Rare and Co-mutations in Oncogenic Driver Genes. Neoplasia 2016, 18, 577-583. [CrossRef] [PubMed]

104. Letovanec, I.; Finn, S.; Zygoura, P.; Smyth, P.; Soltermann, A.; Bubendorf, L.; Speel, E.J.; Marchetti, A.; Nonaka, D.; Monkhorst, K.; et al. ETOP Lungscape Consortium. Evaluation of NGS and RT-PCR methods for ALK rearrangement in European NSCLC patients: Results from the ETOP Lungscape Project. J. Thorac. Oncol. 2018, 13, 413-425. [CrossRef] [PubMed]

105. Rossi, G.; Jocollé, G.; Conti, A.; Tiseo, M.; Zito Marino, F.; Donati, G.; Franco, R.; Bono, F.; Barbisan, F.; Facchinetti, F. Detection of ROS1 rearrangement in non-small cell lung cancer: Current and future perspectives. Lung Cancer 2017, 8, 45-55. [CrossRef] [PubMed]

106. Rapisuwon, S.; Busam, K.J.; Parks, K.; Chapman, P.B.; Lee, E.; Atkins, M.B. Discordance Between Cobas BRAF V600 Testing and VE1 Immunohistochemistry in a Melanoma Patient with Bone Marrow Metastases. Am. J. Dermatopathol. 2016, 38, 687-689. [CrossRef] [PubMed]

107. Kao, H.L.; Yeh, Y.C.; Lin, C.H.; Hsu, W.F.; Hsieh, W.Y.; Ho, H.L.; Chou, T.Y. Diagnostic algorithm for detection of targetable driver mutations in lung adenocarcinomas: Comprehensive analyses of 205 cases with immunohistochemistry, real-time PCR and fluorescence in situ hybridization methods. Lung Cancer 2016, 101, 40-47. [CrossRef] [PubMed]

108. Vincenten, J.P.; Smit, E.F.; Grünberg, K.; Postmus, P.E.; Snijders, P.J.; Witte, B.I.; Heideman, D.A.; Thunnissen, E. Is the current diagnostic algorithm reliable for selecting cases for EGFR- and KRAS-mutation analysis in lung cancer? Lung Cancer 2015, 89, 19-26. [CrossRef] [PubMed]

109. Williams, A.S.; Greer, W.; Bethune, D.; Craddock, K.J.; Flowerdew, G.; Xu, Z. ALK+ lung adenocarcinoma in never smokers and long-term ex-smokers: Prevalence and detection by immunohistochemistry and fluorescence in situ hybridization. Virchows Arch. 2016, 469, 533-540. [CrossRef] [PubMed]

110. Campesato, L.F.; Barroso-Sousa, R.; Jimenez, L.; Correa, B.R.; Sabbaga, J.; Hoff, P.M.; Reis, L.F.; Galante, P.A.; Camargo, A.A. Comprehensive cancer-gene panels can be used to estimate mutational load and predict clinical benefit to PD-1 blockade in clinical practice. Oncotarget 2015, 6, 34221-34227. [CrossRef] [PubMed]

111. Goodman, A.M.; Kato, S.; Bazhenova, L.; Patel, S.P.; Frampton, G.M.; Miller, V.; Stephens, P.J.; Daniels, G.A.; Kurzrock, R. Tumor Mutational Burden as an Independent Predictor of Response to Immunotherapy in Diverse Cancers. Mol. Cancer Ther. 2017, 16, 2598-2608. [CrossRef] [PubMed]

112. Soo, R.A.; Lim, S.M.; Syn, N.L.; Teng, R.; Soong, R.; Mok, T.S.K.; Cho, B.C. Immune checkpoint inhibitors in epidermal growth factor receptor mutant non-small cell lung cancer: Current controversies and future directions. Lung Cancer 2018, 115, 12-20. [CrossRef] [PubMed] 
113. Gorris, M.A.J.; Halilovic, A.; Rabold, K.; van Duffelen, A.; Wickramasinghe, I.N.; Verweij, D.; Wortel, I.M.N.; Textor, J.C.; de Vries, I.J.M.; Figdor, C.G. Eight-color multiplex immunohistochemistry for simultaneous detection of multiple immune checkpoint molecules within the tumor microenvironment. J. Immunol. 2018, 200, 347-354. [CrossRef] [PubMed]

114. Mezheyeuski, A.; Bergsland, C.H.; Backman, M.; Djureinovic, D.; Sjöblom, T.; Bruun, J.; Micke, P. Multispectral imaging for quantitative and compartment-specific immune infiltrates reveals distinct immune profiles that classify lung cancer patients. J. Pathol. 2017. [CrossRef] [PubMed]

115. Parra, E.R.; Uraoka, N.; Jiang, M.; Cook, P.; Gibbons, D.; Forget, M.A.; Bernatchez, C.; Haymaker, C.; Wistuba, II.; Rodriguez-Canales, J. Validation of multiplex immunofluorescence panels using multispectral microscopy for immune-profiling of formalin-fixed and paraffin-embedded human tumor tissues. Sci. Rep. 2017, 7, 13380. [CrossRef] [PubMed]

116. Roussel, H.; De Guillebon, E.; Biard, L.; Mandavit, M.; Gibault, L.; Fabre, E.; Antoine, M.; Hofman, P.; Beau-Faller, M.; Blons, H.; et al. Composite biomarkers defined by multiparametric immunofluorescence analysis identify ALK-positive adenocarcinoma as a potential target for immunotherapy. Oncoimmunology 2017, 6, e1286437. [CrossRef] [PubMed]

117. Ilie, M.; Hofman, V.; Long, E.; Bordone, O.; Selva, E.; Washetine, K.; Marquette, C.H.; Hofman, P. Current challenges for detection of circulating tumor cells and cell-free circulating nucleic acids, and their characterization in non-small cell lung carcinoma patients. What is the best blood substrate for personalized medicine? Ann. Transl. Med. 2014, 2, 107. [CrossRef] [PubMed]

118. Ilie, M.; Szafer-Glusman, E.; Hofman, V.; Long-Mira, E.; Suttmann, R.; Darbonne, W.; Butori, C.; Lalvée, S.; Fayada, J.; Selva, E.; et al. Expression of MET in circulating tumor cells correlates with expression in tumor tissue from advanced-stage lung cancer patients. Oncotarget 2017, 8, 26112-26121. [CrossRef] [PubMed]

119. Ilie, M.; Szafer-Glusman, E.; Hofman, V.; Chamorey, E.; Lalvée, S.; Selva, E.; Leroy, S.; Marquette, C.H.; Kowanetz, M.; Hedge, P.; et al. Detection of PD-L1 in circulating tumor cells and white blood cells from patients with advanced non-small-cell lung cancer. Ann. Oncol. 2017, 29, 193-199. [CrossRef] [PubMed]

120. Hofman, P. Liquid Biopsy and Therapeutic Targets: Present and future issues in thoracic oncology. Cancers 2017, 9, 154. [CrossRef] [PubMed]

121. Ilié, M.; Hofman, P. Pros: Can tissue biopsy be replaced by liquid biopsy? Transl. Lung Cancer Res. 2016, 5, 420-423. [CrossRef] [PubMed]

122. Mayo-de-Las-Casas, C.; Garzón Ibáñez, M.; Jordana-Ariza, N.; García-Peláez, B.; Balada-Bel, A.; Villatoro, S.; Malapelle, U.; Karachaliou, N.; Troncone, G.; Rosell, R.; et al. An update on liquid biopsy analysis for diagnostic and monitoring applications in non-small cell lung cancer. Expert. Rev. Mol. Diagn. 2018, 18, 35-45. [CrossRef] [PubMed]

123. Hofman, V.J.; Ilie, M.; Hofman, P.M. Detection and characterization of circulating tumor cells in lung cancer: Why and how? Cancer Cytopathol. 2016, 124, 380-387. [CrossRef] [PubMed] 